Division of Research

February 1990, Revised May 1992

School of Business Administration

CONTRACTUAL ARRANGEMENTS AS

SIGNALING DEVICES:

EVIDENCE FROM FRANCHISING

Working Paper \#688

Francine Lafontaine

The University of Michigan

COPYRIGHT 1990, 1992

The University of Michigan

School of Business Administration

Ann Arbor, Michigan 48109-1234 


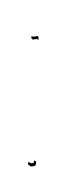

-

$-$

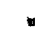$$
\text { r }
$$ 


\begin{abstract}
This paper's contribution is to provide an empirical assessment of the proposition, derived in recent theoretical work on franchising, that signaling can explain firms' contractual decisions vis-à-vis their franchisees. According to this literature, high-value franchisors with no established reputation will choose to offer a franchise contract and a contract mix that will make their revenues highly dependent on the performance of their outlets. This is done so as to convince franchisees of the high value of their franchises. Hence they will pick a contract with a high royalty rate and a low franchise fee, and will tend to operate $a$ large proportion of their outlets directly. Low-value franchisors, on the other hand, will opt for more fixed fees and leșs variable payments.

In this paper, these implications are tested by relating franchisors' observed choices of royalty rates, franchise fees and tendency to operate outlets directly at the time they begin franchising to a measure of their type. The latter is based on each chain's measured rate of growth in the years that follow its involvement in franchising. The empirical results are not supportive of the signaling explanation for the terms of the franchise contract (royalty rates and franchise fees), or for franchisor's tendency to operate outlets directly. Reasons why this might be the case are discussed in the conclusion. Mostly, I argue that signaling cannot explain the terms of long term contracts such as those found in franchising because the longer the relationship, a) the more likely it is that alternative cheaper signals will exist, and more importantly b) the more likely it is that the information the uninformed party needs is in fact not exogenously given and fixed, but rather depends on the future behavior of the informed party. Hence as suggested by the existing empirical evidence on franchising, royalties on sales, and possibly company-owned outlets, are used not as signals, but more likely as incentive mechanisms that reassure the franchisee as to the future behavior of the franchisor, and therefore as to the future value of the franchise.
\end{abstract}




\title{
CONTRACTUAL ARRANGEMENTS AS SIGNALING DEVICES: EVIDENCE FROM FRANCHISING
}

\author{
by
}

\author{
Francine Lafontaine*
}

\section{Introduction}

In the presence of asymmetric information, the notion that firms may use a variety of instruments to provide relevant information about themselves or their product is now well established in industrial organization. For example, pricing, advertising and warranty decisions have all been suggested as means by which a firm can signal the quality of its product. (See notably Wolinsky (1983), Cooper and Ross (1984), and Kihlstrom and Riordan (1984); the possibility that firms may use multiple signals is examined in Milgrom and Roberts (1986), Matthews and Moore (1987) and Wilson (1985) among others.)

Recently, this type of reasoning has also been applied to the area of contractual arrangements. More specifically, Gallini and Wright (1987) and (1990) argue that the use of royalties on sales in licensing agreements might be explained by the need for the licensor to signal the value of the offered technology. A similar point is made relative to vertical relationships in general, and franchising contracts in particular, in Tirole (1988, p. 177 and p. 453). Finally, Gallini and Lutz (1992) argue that not only can the use of royalty rates act as a signal to potential franchisees, but so can the proportion

* Graduate School of Industrial Administration, Carnegie Mellon University and School of Business Administration, University of Michigan. Financial support from the National Science Foundation, grant no. SES-8908646, and from the Graduate School of Industrial Administration is gratefully acknowledged. As required by the NSF, the data set used in this paper has been deposited with the Inter-University Consortium for political and social research (ICPSR). I would like to thank Stan Baiman, Steve Donald, Nancy Gallini, Nancy Lutz, Subrata Sen, Kathy Shaw, Margaret Slade, Kannan Srinivasan, and particularly Sugato Bhattacharyya for helpful comments and discussions, as well as Robert Picard for his assistance. I am also grateful to workshop participants at the Antitrust Division of the Dept. of Justice, the Federal Trade Commission Bureau of Economics, the MIT Dept. of Economics, the University of Pittsburgh Dept. of Economics, the Yale School of Management, and the University of Michigan Graduate School of Business Administration for useful comments. All errors are of course mine. An earlier version of this paper was entitled "An Empirical Look at Franchising Contracts as Signaling Devices" and was circulated as GSIA working paper 1990-19, Carnegie Mellon University. 
of outlets franchisors choose to operate directly rather than franchise. In fact, theirs is the first model of franchising to explain directly the use of dual distribution, that is franchisors' tendency to operate some stores directly and to franchise the others. Other theories of franchising must rely on outlet heterogeneity and limitations on the variety of contracts that can be used to give rise to dual distribution. ${ }^{1}$

This paper's contribution is to provide an empirical assessment of this proposition, derived from the theoretical literature, that signaling may explain franchisors' choices of royalty rates and franchise fees, as well as their tendency to operate outlets directly. Franchisors' observed choices of royalty rates, franchise fees and proportion of company-owned outlets at the time they begin franchising are related empirically to a measure of their types. The latter is based on each chain's rate of growth in its number of outlets in the years that follow its involvement in franchising.

This analysis of whether or not franchise contracts serve a role as signaling devices should be useful in at least two respects. First, it guides us in the process of identifying the theories that can best explain franchising. This is important given that franchising has become a very prevalent type of organizational arrangement in the U.S. economy. At present, it is estimated that more than one third of all retail sales occur through outlets of franchised companies. ${ }^{2}$

Second, because it provides an empirical test of the importance or relevanve of signaling in a particular context, this paper allows us to better evaluate the empirical importance and/or relevance of signaling theory in general. Given that signaling theory has been and continues to be applied to a number of different issues, it is important that we assess its empirical relevance, and that we begin to determine the circumstances under which signaling may be more or less important as an explanation for a particular phenomenon. Yet to date, very little empirical work has been done in this area in industrial organization. ${ }^{3}$

1 See Lafontaine (1992a) for more on this. Also, Desai and Srinivasan (1990) examine the effect of introducing franchisee moral hazard in a signaling model of franchising.

2 See Dept. of Commerce (1988).

3 A number of empirical analyses of signaling models have been carried out in finance and accounting. These are concerned notably with dividend policy or debt/equity ratios as signals of firms quality, or with common stock repurchases at a premium or the underpricing of new issues as signals of the same. (See for example Vermaelen (1981), Downes and Heinkel (1982) and Balvers, McDonald and Miller (1988), and the references therein.) In general, the results reported in the finance literature are supportive of the signaling explanation for the phenomena 
Clearly, one finds a number of explanations for franchising in the literature that are not based on signaling. These theories include risk-sharing (see for example Stiglitz (1974), although he is concerned with sharecropping rather than franchising), franchisee moral hazard (Mathewson and Winter (1985)), two-sided moral hazard (Rubin (1978), Lal (1990) and Bhattacharyya and Lafontaine (1992)), screening (e.g. Hallagan (1978), also on sharecropping) and the traditional explanation for franchising based on capital market imperfections (e.g. Caves and Murphy (1975)). The empirical implications of these theories have been tested elsewhere (see notably Brickley and Dark (1987), Norton (1988) and Lafontaine (1992a)). I do not address these here because the framework needed to assess the implications of the signaling model does not readily lend itself to drawing conclusions about other theories. However, these alternative explanations imply that other factors, such as riskiness and incentive considerations, are likely to play a role in the design and use of franchise contracts. One must control for such effects in the empirical analysis. As a result, while the signaling explanation remains the focus of this paper, some of the results obtained herein will bear on alternative models as well.

The paper is organized as follows. The empirical implications from a representative signaling theory of franchising are derived in the next section. The data used in the empirical analysis, as well as the issues that arise when trying to use these data to assess the validity of the signaling explanation, are described in Section 3. The methodology and empirical results are found in Section 4. Section 5 contains some additional discussion of relevant evidence while Section 6 concludes.

\section{Deriving Empirical Implications from the Representative Signaling Explanation of Franchising}

A franchise agreement is defined as a contractual arrangement between two independent firms, whereby the franchisee pays the franchisor for the right to sell the franchisor's product and/or the right to use his trademark at a given place and for a certain period of time. In business format franchising, franchise contracts

they study. However, in the marketing literature, the empirical evidence has not been very supportive of either the positive price-quality relationship implied by signaling models, (see Gerstner (1985), Wiener (1985), and Curry and Riesz (1988), and the references therein) and the warranty-quality relationship suggested by such models (see Gerner and Bryant (1981), Priest (1981) and Garvin (1983)). One exception is Wiener (1985) who finds that product warranties do signal product reliability. 
typically involve the payment, by the franchisee to the franchisor, of a proportion of the former's sales in royalties. ${ }^{4}$ This proportion is usually constant over all sales levels. ${ }^{5}$ In addition, franchisors almost always require a lump-sum franchise fee which is paid upfront, and only once for the duration of the contract.

Since franchising involves the transfer from the franchisor to the franchisee of a tradename and whole way of doing business, which are basically intangible assets, it has been argued that it is difficult for the buyer to assess the value of these assets a priori. This is especially true for potential franchisees interested in new franchise systems, i.e. in systems offered by franchisors with no established reputation. This is emphasized in the trade literature by the pervasive calls for franchisees to "investigate before they invest".

In the theoretical literature, authors have analyzed this informational advantage of the franchisor and developed an explanation for franchising and franchise contracts that relies on franchisors' need to signal their type to potential franchisees. This signaling explanation has been used to explain franchisors' choices of contract terms, namely their royalty rates and franchise fees, (see Gallini and Wright (1990) on licensing contracts, and Tirole (1988), Gallini and Lutz (1992) and Desai and Srinivasan (1990) on franchising) as well as their tendency to operate outlets directly (Gallini and Lutz (1992)). This section discusses the empirical implications of the above models in the context of franchising. The interested reader is referred to Appendix A for a description of a representative signaling model as it has been applied to franchising, as well as a more systematic derivation of the testable implications.

The main insight from the signaling literature in the context of linear payment

4 The U.S. Department of commerce (1988) classifies franchises according to the main component of the transaction: "Product and Tradename Franchising", also referred to as "Traditional Franchising", is characterized by franchised dealers who "concentrate on one company's product line and to some extent identify their business with that company" (p. 1). This type of franchising is limited to car dealerships, soft-drink bottlers and gasoline service stations. In "Business Format Franchising" on the other hand, the relationship between franchisor and franchisee "includes not only the product, service, and trademark, but the entire business format itself - a marketing strategy and plan, operating manuals and standards, quality control, and continuing two way communication" (p. 3). Examples include restaurants, business and employment services, and real estate agencies. The word franchising should be interpreted to mean business format franchising in the remainder of this paper.

5 In Lafontaine (1992b), 93 of the 117 respondents said that their royalty rate was constant over all sales levels. Another 20 said it was piece-wise linear, with 18 of them using a sliding scale and 2, an increasing scale. The remaining respondents said "other". 
rules such as those used in franchising is that a "good" franchisor, who has not yet established his reputation, can signal his type by offering a contract that makes his revenues highly dependent upon the performance of the outlet. The argument is very similar to that found in Leland and Pyle (1977), where entrepreneurs can convince potential investors of the value of their project by investing more in it themselves. In other words, the contract a "good" franchisor should offer to differentiate or separate himself from a "bad" franchisor would involve a higher royalty rate, and lower franchise fee, to the point where a bad type would find it unprofitable to imitate. (See Gallini and Wright (1987) and (1990), and Tirole (1988).) The reason why the bad franchisor finds it unprofitable to imitate this contract is that the imposition of royalty rates leads to distortions in franchisees' price and quantity decisions due to double marginalization. It is assumed that the reduction in revenues arising from increases in the royalty rates are greater for bad franchisors than they are for good types (this is the usual sorting condition in signaling; see Appendix A). Hence, in equilibrium, the good type will be able to separate from the bad type by choosing a royalty rate high enough, and a correspondingly low enough franchise fee. The bad type, unable to profitably imitate this contract, will opt for a contract with no royalties, i.e. a contract inducing no distortions downstream. In other words, in equilibrium, the royalty rate for the good type will be higher than the royalty rate of the bad type, which is zero. At the same time, it can be shown that the franchise fee of the good type will necessarily be smaller than the franchise fee of the bad type (see Appendix A).

Extending the argument to a continuum of types, the testable implications from the signaling model are as follows:

A1: For franchisors with no established reputation, holding other factors constant, the royalty rate, $r$, increases with the franchisor's type $T$.

A2: For franchisors with no established reputation, holding other factors constant, the franchise fee, $F$, is a decreasing function of the franchisor's type $T$.

Note that as a result of these two relationships, we should also find that the franchise fee $F$ and the royalty rate $r$ are inversely related. This will be the case here irrespective of whether or not the franchisee's participation constraint is binding. In most other models of franchising, a negative correlation between the two fees would arise because 
franchisees are kept at their reservation level of utility, i.e. franchisee's participation constraints are binding.

The focus of the above discussion was on franchisors' capacity to signal through the terms of their franchise contracts. The argument underlying this result is that franchisors can signal their type by making their revenues depend on the value of the franchise. As noted in Gallini and Lutz (1992), beside levying royalties based on outlets' sales, franchisors can make their revenues depend on the overall value of their franchise by operating outlets directly. And most franchisors do own and operate a number of their outlets. ${ }^{6}$ Hence Gallini and Lutz (1992) suggest that signaling might explain not only the use of royalties in franchising, but also why it is that franchisors operate some of their units, while franchising the others.

Three types of equilibria may possibly occur in this type of model. First, it could be that franchisors would decide not to use company-ownership as a signal, in which case all signaling would again be achieved through the terms of their franchise contract. Hence the testable implications would still be A1 and A2. Alternatively, signaling may be done completely through franchisors' choice of contract mix, and not at all through the terms of the franchise contract. In that case, in equilibrium, the good franchisor will signal his type by relying heavily on company-ownership, while the bad franchisor, unable to imitate, will choose not to operate any outlets directly. Extending this argument to a continuum of types, we have the following testable implication:

B1: For firms with no established reputation, holding other things constant, the proportion of company-operated outlets, $\alpha$, increases with the franchisor's type, $T$.

Finally, both company-owned outlets and royalty rates may be used as signals. In reality, however, even if firms use both of these to signal their type, there is still only one basic signal. In both cases, high-value franchisors differentiate themselves from lower-value chains by making their revenues depend on the value of their franchise. And the extent to which their revenues do depend on downstream sales, i.e.

\footnotetext{
6 See for example Lafontaine (1992a): 431 of her 548 franchisors operated outlets directly. The average proportion of company-operated stores across the 548 firms was $17.25 \%$. In fact, dual distribution is so much a part of franchising that most of the empirical work to date in this area has focused on explaining the franchise versus company own decision. See also Brickley and Dark (1987), Martin (1988), Norton (1988) and Minkler (1990).
} 
franchisors' stakes in downstream operations, can be estimated through a combination of their royalty rates and their reliance on company-ownership. If the contract mix and/or royalty rates are used as signaling devices, we should find that this stake increases with the franchisor's type, i.e. that:

C1: For franchisors with no established reputation, holding other things constant, the franchisor's stake in downstream operations, which reflects both his royalty rate and his tendency to operate outlets directly, is increasing in his type $T$.

In addition, if both signals are used, given a franchisor's type, the royalty rate and the use of company-ownership should be negatively correlated. The two signals are basically substitutes so that, as one signal is used more to achieve the desired level of dependency of the franchisor's revenues on the outlets' performance, the other should be used less. Which combination of royalties and company-owned outlets is actually used will depend on the relative cost and efficiency of each. Hence we have:

C2: For a given type $T$, the proportion of company-owned outlets, $\alpha$, and the royalty rate $r$, are negatively correlated.

Finally, if the franchisee's participation constraint is binding, the franchise fee and the royalty rate should again be negatively correlated, but the franchise fee need not be decreasing, and the royalty rate increasing, in the type of the franchisor when both signals are used simultaneously.

\section{Available Data and Measurement Issues}

One can obtain a significant amount of data on franchising and on franchise contracts from public sources. The Entrepreneur Magazine's yearly survey Franchise 500 provides most of the data on individual franchisors used in this paper. Other sources were used mostly to settle inconsistencies in the Entrepreneur surveys, although the the Dept. of Commerce's Franchise Opportunities Handbook was also used as a source of additional information on individual franchisors. Entrepreneur's surveys cover an average of about 1000 franchisors each year, and collect information on royalty rates, advertising fees, franchise fees, the number of company-owned and the number of franchised outlets in the chain. The surveys also include information relative to the year in which the firm began its operation, the year in which it became involved in franchising, the type of business it is involved in and the amount of capital required 
to open an outlet. The earliest usable survey covers data for 1980, and the last survey available at the time of this research contained the 1989 data. ${ }^{7}$

A number of issues arise when trying to adapt these data to test the hypotheses developed in Section 2. First there are direct measurement issues, such as how the above data on fees must be transformed to correspond to their theoretical equivalent. Second, there are problems in trying to capture constructs such as the franchisor's type and the franchisor's stake in downstream operations using the available information. Finally, the theory and the data impose constraints on the sample of franchisors to be studied here. The remainder of this section describes the approaches used, and the compromises made, in making the necessary adjustments.

\subsection{Measurement Issues: Contract Terms}

At a given point in time, the royalty rate and franchise fee demanded by a franchisor tend to be the same for all potential franchisees. ${ }^{8}$ This is not to say that these fees do not vary over time or across franchisors, but simply that they are fixed for certain periods of time for new contracts within a franchised chain. As a result,

7 The first survey was really done in 1979 . Unfortunately, in this case, the advertising fee was not reported.

8 This is not clear from the Entrepreneur's surveys, which are the main sources of the data used here. About $30 \%$ of the franchisors each year in that survey either give a range for their fixed fees, their royalty rates or their advertising fees, or they say that they vary. However, discussions with franchisors and a detailed look at disclosure statements provided to me by franchisors ( 56 of them) reveals that varying fees or ranges generally mean one of a variety of things. First, some franchisors offer different types of businesses, e.g. a full scale restaurant and a food-mart version of the same, which call for different fees, both variable and fixed. Second, a range for the royalty rate ( 84 occurences out of 1048 franchisors in the 1988 survey) generally means that the franchisor uses a sliding scale to calculate royalties, or that a different rate will be charged for the first few years of operation. When franchisors say that their royalty rates vary, which is fairly rare ( 49 occurences in the 1988 survey), this generally means that different services are offered to franchisees, and that these are assigned different rates. Varying advertising fees or ranges in these (58 cases out of 1048) tend to mean that they will change through time, not across franchisees, as the need arises during the period of the contract. Finally, fixed fees sometimes vary with the size of the operation, i.e. the size of the assigned territory (197 cases out of 1048). Notice that many franchisors gave ranges or said the fee varied for more than one fee, which explains why the total proportion of franchisors with varying fees is $30 \%$ and not the almost $40 \%$ implied by the above numbers. Of course, cases where fees were simply said to vary were eliminated from my data since it is impossible to assign fees to these firms. However, under the assumption that the average fee represents the average outlet in the chain, averages were used for those that indicated a range. 
one can refer to, and examine empirically, the terms of the franchise contracts (royalty rates and franchise fees) offered by various franchisors.

While the terms of franchise contracts tend to be the same for all franchisees, which is an advantage in doing empirical research in this area, some issues arise in transforming the data on fees to correspond to their theoretical equivalent. Because the royalty rates and franchise fees used in the empirical analysis should represent all the variable and fixed payments from the franchisee to the franchisor, when the advertising fee is given as a percentage of sales, I combine it with the stated royalty rate to generate what I refer to as the royalty rate in this paper. Also when the advertising fees are given as a fixed amount per time period, they are discounted and added to the franchise fee. Similarly, when royalties are given as a fixed amount per time period, royalty rates are taken to be zero, while the discounted value of these fixed payments are added to the franchise fee. ${ }^{9}$ Finally, all franchise fees are transformed to 1980 U.S. dollars, and expressed in thousands of dollars. Royalty rates and other proportions are in percentages. ${ }^{10}$

\subsection{Measurement Issues: Capturing Theoretical Constructs}

Establishing differences in behavior between high and low-value franchises requires that one measures their type $T$. One of the best measures would undoubtedly be based on future realized profits, either at the outlet level or the chain level, since those two should be highly correlated. Unfortunately, data on profits are unavailable. However, because of the geographical nature of the types of businesses that are franchised, total sales and profits for the chain tend to be highly correlated with the number of outlets. In other words, a growing chain is a profitable chain. Hence, as a second best, I use information on the level of growth in number of outlets in the

${ }^{9}$ In reality, fixed up-front fees and ongoing fixed payments are different in that the obligation to pay the latter disappears if the outlet goes out of business during the period of the contract. Since failure rates are rather low in franchising (see Franchising in the Economy, 1986-88: the number of discontinued outlets in 1986 was 7934, while the total number of business format franchises was 246,664 , for a discontinuation rate of about $3.2 \%$ per year), and ongoing fixed payments are also uncommon ( 4 cases out of 125 in the present sample), I decided to disregard this difference. The discount rate used was $10 \%$ since these fees are in nominal dollars. Given the small number of cases where ongoing fixed payments occur, results are not sensitive to this procedure.

10 Some of the franchisors in the sample are Canadian. Their franchise fee was transformed to SU.S. 
years that follow the chain's involvement in franchising to measure the value of the tradename. ${ }^{11}$ The growth rate is measured as the difference in the logarithm of the number of outlets between two time periods at least five years apart, yet as close as possible to five years apart. The resulting growth rate is then further divided by the number of years between the two observations on each firm to correct for the fact that the period between observations varies from 5 years to 8 years given the available data. $^{12}$

We know from Jovanovic (1982) that a firm's growth rate is likely to decline as it becomes more mature. For that reason, the actual measure of growth used here to capture the type of the firm is the deviation of the firm's rate of growth from its expected rate of growth given its age. In other words, the actual measure of type is the error term from a regression of the growth rate on the number of years that a firm was in business before it began franchising. The reciprocal functional form was used for this regression as it proved most satisfactory in this case. Consistent with Jovanovic's model, franchisors' growth rates were significantly inversely related to their age. ${ }^{13}$

Finally, one drawback associated with using a measure based on the growth rate in the number of outlets to capture the intrinsic value of the franchise or tradename is that low-quality or even fraudulent franchisors may succeed in getting a large number of franchisees to invest in their system initially. As a result, their initial growth in number of outlets would be very large, despite their being of low-quality. This is why I have chosen to measure growth in the number of outlets over a period of no less than 5 years. Choosing a relatively long period to measure growth should minimize the effect that early phenomenal growth of low-quality franchised chains might have on the results. In addition, I examine how sensitive results are to initial growth by contrasting those obtained over the whole five-year plus range with results obtained

11 Measures of "success" based on outlets are used quite frequently in the trade literature on franchising. See for example Venture's The Franchise 100.

12 Results were the same when the growth rate was measured as the proportional change in the number outlets. Results were also unchanged when the growth rate in the number of franchises only was considered. Since I was interested in measuring the change in profitability, growth in the total number of outlets seemed a more appropriate measure.

13 An attempt was also made to control for the number of outlets a firm had as it became involved in franchising, but the coefficient for this variable was never significant. It is worth pointing out that the qualitative results presented in this paper remain the same if the growth rate is used directly as the measure of type. 
when the measure of growth is limited to the last two of these five or plus years. This last measure may be interpreted as a measure of sustained growth for the franchised chain, and in that sense may be a better measure of type than the former. These two ways of measuring growth are referred to as Growth1 and Growth2 in the remainder of this paper, while after controlling for the firm's expected growth rate given its age, they become Type1 and Type2 respectively.

One problem with implementing a test of a franchisor's reliance on company ownership as a signal is that by definition, those firms that need to signal their types are just becoming involved in franchising. Consequently, their initial proportion of company-owned stores is necessarily $100 \%$. In that case, the initial number of company-owned outlets must serve as the signal, giving franchisees some idea about what they might expect the proportion of company-operated outlets to be over the next few years. Since one would expect that there would be a diminishing marginal "signaling" benefit to the franchisor from owning additional outlets, one should use a transformation of the number of company-owned outlets the firm has when it starts franchising as the measure of the signal. I do this in two different ways: First, I use the logarithm of the number of such outlets as the measure of the signal. ${ }^{14}$ Second, I calculate what the proportion of company-owned outlets is expected to be after " $t$ " years, given the number of franchises a typical franchisor opens up during his first "t" years in franchising. This assumes that the number of company-operated outlets remains constant at the initial level of $c_{0}$, which is well supported by the data. In other words, we have

$$
\alpha_{t}=c_{0} /\left(c_{0}+f_{t}\right)
$$

where $f_{t}$ is the number of franchised units typically opened within $t$ years in franchising. The median number of franchised units opened during the first 3 (5) years in franchising, $f_{3}\left(f_{5}\right)$, was found to be $20(32)$ for the firms in the present sample.

To implement a test for the case where firms use both $r$ and $\alpha$ to signal their type, given a measure such as $\alpha_{t}$ for $\alpha$, one can estimate the stake the franchisor has in downstream operations by combining royalties and company-ownership. If average

14 In reality, because this number of company-owned outlets is zero for 20 of the 125 firms in this sample, and $\log (0)$ is not defined, I added .5 to the number of outlets before taking the logarithm. Results obtained using the number of company-owned outlets directly were equivalent to those reported here. 
sales per outlet were about the same in franchised and company-operated units,

$$
S_{t}=\alpha_{t}+\left(1-\alpha_{t}\right) \cdot r / 100
$$

would give the expected share $\left(S_{t}\right)$ of the chain's revenues that is appropriated directly by the franchisor at time $t$. But average sales per company-owned outlets tend to be larger than those of franchised units. ${ }^{15}$ Consequently, $S_{t}$ is estimated by

$$
S_{t}=\frac{\alpha_{t} \cdot \text { AvSales }^{c}+\left(1-\alpha_{t}\right) \text { AvSales }^{f} \cdot r / 100}{\alpha_{t} \cdot \text { AvSales }^{c}+\left(1-\alpha_{t}\right) \text { AvSales }^{f}}
$$

where $A_{v S a l e s}{ }^{c}$ and AvSales $^{f}$ refer respectively to average sales per company-owned and per franchised outlet, at the time the firm becomes involved in franchising. Unfortunately, data on average sales per outlet are unavailable for individual franchisors. Aggregate data on sales per company-operated and franchised outlets are available on a sectoral basis from the U.S. Department of Commerce's Franchising in the Economy for the appropriate years. ${ }^{16}$ Assuming that the relative magnitude of these average sales is fairly constant for franchisors in the same sector, using these data in equation (3.3) should provide a good approximation for $S_{t}$.

Finally, one may assume that firms continue to signal their types for a few years beyond the time at which they actually become involved in franchising. In that case, the actual proportion of company-owned outlets, $\alpha_{a}$ and the actual $S_{a}$ (estimated from (3.3) given $\alpha_{a}$ ) 3 or 4 years after the firm gets involved in franchising may also be used to measure $\alpha$ and $S$ respectively. Specifically, $\alpha_{a}$ and $S_{a}$ are measured 2 years before the end of the 5 year plus period separating the two observations on each firm. This is because for any given survey year $t$, the number of franchised and company-owned outlets is given for years $t, t-1$ and $t-2$. Since I observe each firm in 2 surveys 5 or more years apart, I can use the data for $t-2$ in the second

15 See Franchising in the Economy, 1986-88, Table 19 for the 1986 figures.

16 The business format franchising sectors defined by the D.O.C. are the following: 1- Automotive Products and Services, 2- Business Aids and Services, 3- Construction, Home Improvement, Maintenance and Carpet Cleaning, 4- Convenience Stores, 5- Educational Products and Services, 6- Restaurants, 7- Hotels, Motels and Campgrounds, 8- Laundry and Drycleaning Services, 9- Recreation, Entertainment and Travel, 10- Rental Services (Auto-Trucks), 11Rental Services (Equipment), 12- Non-Food Retailing, 13- Food Retailing, Non-Convenience, 14- Miscellaneous. In the case of Business Services and Restaurants, some data are also broken down by subsectors such as, for Restaurants, 1- Chicken, 2- Hamburgers, Franks, Roast Beef, 3- Pizza, and so on. 
observation to construct $\alpha_{a}$ and $S_{a}$. By so doing, I avoid imposing a requirement of observing the firm in an additional survey between the two original observations, which would have reduced my sample size. ${ }^{17}$

\subsection{Sampling Constraints}

Since the signaling model addresses the issue of how a new franchisor can convey information about himself through his initial contract mix and contract terms, only firms that began franchising since the first survey was done can be included in the sample. This eliminates well-established franchisors such as McDonald's and Burger King, both of whom started franchising around 1955. But because the calendar years do not provide appropriate cut-off points, I chose to include those firms that started franchising in year $t-1$ if they appear in the year $t$ survey but did not appear in the $t-1$ survey. This allows firms that might have become involved in franchising late in a given year to be included in the sample if they report their fees and contract mix in the following year's survey. The latter reports are interpreted as initial contract offerings and contract mixes in such cases.

In addition, the need to assess a firm's type requires that information relative to its number of outlets be available at least 5 years later. Given the available survey years, this implies that the sample is limited to those firms that began franchising after 1979 , so that we can observe their initial contract terms, and for which data on the number of outlets at least five years later is available by 1989 . The latter implies that franchisors must have been franchising between 1979 and 1984 in order to be included in the sample. Note that because the first usable survey is for 1980, the 5 -year difference required to calculate growth implies that even firms that became involved in franchising in 1979 must be observed again in 1985 or later since their initial data are in fact for 1980. A total of 168 franchisors were found to fulfill these conditions across the ten surveys. Missing or inconsistent data led to the rejection of an additional 43 of these, resulting in a final sample of 125 franchisors.

17 The fact that the number of years elapsed between the beginning of franchising and the time I observe $\alpha_{a}$ and $S_{a}$ varies a little across firms (the number of years is either 3 or 4 for 120 firms out of 125) is not a problem in the regressions since I control for the year in which the firm began franchising. Note that the royalty rate in the final survey is used in combination with $\alpha_{a}$ to generate $S_{a}$. 
Clearly, the requirement that firms be observed at two points in time at least five years apart implies that only relatively successful firms, i.e. firms that survive at least five years, are included in this sample. This in turn creates the possibility of a selection problem. This problem is not addressed econometrically here for a number of reasons. First, as noted in Appendix A, for separation to occur, it is necessary that the "bad" franchisors be profitable. Hence there is a theoretical reason for excluding firms that fail from the sample under study here. ${ }^{18}$ Second, on a pragmatic basis, it is not possible, using the available survey data, to infer franchisor survival. In other words, the absence of a franchisor from the survey in a given year cannot be interpreted as a sign of failure. For that reason, it is not possible to identify and then include in the present sample those firms that have failed. Third, and most important, even if the sample under study here did exclude or underrepresent those firms at the bottom of the distribution of types, the theory would still predict, and hence we should still observe over the remaining set of firms, the correlations described in Section 2. In that sense, the results presented in the following section still provide an appropriate test of the theory.

\section{Methodology and Results}

Table 1 gives some descriptive statistics about initial royalty rates, franchise fees, number of company-operated outlets and growth rates. The franchisor in this sample who required the maximum royalty payment when it first started franchising is Jazzercise, a fitness program company. ${ }^{19}$ The firm with the largest franchise fee is Qual Krom, in the automotive service industry. The company that had the greatest number of company-owned outlets when it began franchising was Jack in the Box, a fast food hamburger chain, with 780 units. The company that experienced the greatest level of growth in the present sample according to Growth1 (and Type1) is Sparks Tune-Up, while according to Growth2 (and Type2), it is Fantasy Coachworks

18 In particular, one must be sure to exclude from the sample fly-by-night operators. The reason is that these firms are not "playing the same game". Contrary to the set of firms considered here, they do not care about royalties since they do not really intend to collect any. As a result, they may well choose a relatively high royalty rate, and a low franchise fee. The latter might make it easier to sell a large number of franchises in a very limited amount of time, while the former makes the low franchise fee credible. In other words, these firms do not satisfy the sorting condition: they incur no loss of revenues from increasing $r$.

19 Five years later, this fee was down to $20 \%$. 
Table 1

Descriptive Statistics

\begin{tabular}{lrrrrr}
\hline & N & Mean & $\sigma$ & Minimum & Maximum \\
& & & & & \\
Royalty Rate & 125 & 7.04 & 3.87 & 0.00 & 31.50 \\
Franchise Fee (\$000) & 125 & 14.24 & 11.11 & 0.00 & 79.30 \\
Co-own Units & 125 & 20.96 & 101.65 & 0.00 & 780.00 \\
$\hat{\alpha}$ & 125 & 1.11 & 1.38 & -0.69 & 6.66 \\
$\alpha_{3}$ (3 years) & 125 & 15.93 & 19.72 & 0.00 & 97.50 \\
$\alpha_{5}$ (5 years) & 125 & 11.99 & 18.17 & 0.00 & 96.06 \\
$\alpha_{a}$ (3-4 years) & 125 & 23.96 & 27.02 & 0.00 & 100.00 \\
$S_{3}$ (3 years) & 125 & 29.56 & 21.33 & 0.00 & 99.19 \\
$S_{5}$ (5 years) & 125 & 24.20 & 19.49 & 0.00 & 98.71 \\
$S_{a}$ (3-4 years) & 125 & 37.95 & 30.22 & 0.00 & 100.00 \\
Growth1 (5 years +$)$ & 125 & 0.23 & 0.19 & -0.22 & 0.83 \\
Growth2 (last 2 years) & 125 & 0.13 & 0.20 & -0.44 & 0.69 \\
Type1 (5 years + ) & 125 & 0.00 & 0.17 & -0.44 & 0.42 \\
Type2 (last 2 years) & 125 & 0.00 & 0.20 & -0.54 & 0.59 \\
Years in Bus. & 125 & 6.50 & 9.60 & 0.00 & 52.00 \\
Capital Needed (\$000) & 125 & 96.53 & 171.50 & 1.00 & 1087.5 \\
Input Sales & 125 & 13.11 & 12.27 & 0.18 & 34.59 \\
Days of training & 66 & 13.13 & 11.64 & 2.50 & 62.50 \\
Number of States & 66 & 5.48 & 8.15 & 1.00 & 50.00 \\
\hline
\end{tabular}

Ltd., a chain of "Auto Boutiques".

While this is not shown in the table, it is interesting to note that royalty rates and franchise fees did not tend to vary much over the five year plus period between the two observations on each firm. The average royalty rate declined from 7.04 to 6.65 and the average franchise fee went from 14.24 to 16.21 (thousands of $\$ 1980$ ). Similarly, the number of company-owned outlets went down slightly from an average 
of 20.96 to 19.28 . None of these differences are statistically significant. ${ }^{20}$ These results are consistent with survey results reported in Lafontaine (1992b), and they are supported by Banerji and Simon (1991) who find that the contract terms of their 27 franchisors remained relatively stable during the five to six year period over which they observe them.

Table 1 also gives descriptive statistics for the various measures of the proportion of franchised stores and of the stake the firm has in downstream operations, i.e. $\hat{\alpha}=\log \left(c_{0}\right), \alpha_{t}$ and $S_{t}$ when $t=3$ and 5 years respectively, as well as their actual proportion of company-owned stores and actual stake in downstream operations 3 or 4 years later, $\alpha_{a}$ and $S_{a}$ respectively.

Notice that since most firms operate units directly, and have positive royalty rates, the data, as is, is not really consistent with the notion that firms use strictly their contract terms (first type of equilibrium discussed above) or strictly their mix of company-owned and franchised outlets (second type of equilibrium) to signal their types. Hence, taking these data at face value, we are left only with the possibility that franchisors all use both signals to differentiate themselves.

The data in Table 1 might still be consistent with the first type of equilibrium however if we assume that company-ownership is used for purposes that have nothing to do with signaling: for example, one might argue that firms operate units directly to obtain information about their markets, or to provide training grounds for franchisees, or for various other reasons. Lafontaine (1992b) found that 44 of her 130 respondents indicated that company-owned outlets serve as some sort of information gathering device (sometimes referred to as a "window on the industry"), and 84 said that they were used as research centers and training grounds for new franchisees. ${ }^{21}$ Similarly, if signaling was completely achieved through the contract mix, one might argue that franchisors rely on royalty payments for reasons unrelated to franchising.

As discussed in Section 2, signaling, if it is done through the contract terms and/or through the contract mix, implies that franchisors' types should be positively

20 The statistical tests involved calculating the mean and standard error of the individual differences across firms. Confidence intervals around the mean included zero for all reasonable confidence intervals, for all three variables.

21 Multiple answers were allowed for this question so that the total number of answers was 234, not 130. Still, these two answers were the most frequent, followed by higher margins (28) and control \& consistency (24). 
related to the royalty rate or the proportion of company-owned outlets or the stake of the franchisor in downstream operations. The franchise fee, on the other hand, should be negatively correlated to the type of the franchisors if signaling is done using the terms of the contract. Since these implications are in terms of correlations, the logical first step is to look at correlation coefficients. Table 2 shows the correlation coefficients (rank correlation coefficients in parentheses) among the variables of interest. Results relative to $\alpha_{5}$ and $S_{5}$ are not reported in this and the following tables since they were basically the same as those obtained with $\alpha_{3}$ and $S_{3}$.

From Table 2, it is clear that the relationships predicted by the signaling models do not hold: Only the actual proportion of company-owned outlets, $\alpha_{a}$, and the two measures of the stake the firm has in downstream operations, $S_{3}$ and $S_{a}$, are significantly correlated with measures of future growth. However, these correlation coefficients are negative rather than positive as the theory would have predicted.

One also finds that the initial royalty rates and franchise fees are not significantly negatively correlated with each other in these data. This is consistent with results found in Lafontaine (1992a) and in Banerji and Simon (1991), and it suggests that there might be rents left downstream. ${ }^{22}$

In summary, the descriptive statistics presented here do not provide much support for the signaling explanation. It is possible however that variables that are not controlled for in Table 2 could affect the correlation coefficients, making their interpretation difficult. In the following section, I try to control for these other factors.

\subsection{Controlling for Other Factors}

In this section, I first discuss other variables that may convey information to franchisees about the type of the franchisor and hence would reduce the franchisor's need to signal through the terms of his franchise contract or through company-owned outlets. Second, I argue that it is necessary to control for input sales in considering the relationship between the signals and the types since input sales at a markup could serve as an alternative signal. Finally, I discuss briefly alternative explanations for

22 Mathewson and Winter (1985) argue that queues of potential franchisees for the most popular franchises are an indication that there might be rents left downstream. Kaufmann and Lafontaine (1992) present evidence that suggests the existence of downstream rents at McDonald's. 
Table 2

Correlation Coefficients

(Rank Correlation Coefficients in Parentheses)

\begin{tabular}{|c|c|c|c|c|c|c|c|c|c|}
\hline & Royalty & Fran. Fee & Co-own U. & $\alpha_{3}$ & $\alpha_{a}$ & $S_{3}$ & $S_{a}$ & Type 1 & Type 2 \\
\hline Royalty & $\begin{array}{c}1.0 \\
(1.0)\end{array}$ & & & & & & & & \\
\hline Fran. Fee & $\begin{array}{c}-0.10 \\
(-0.03)\end{array}$ & $\begin{array}{c}1.0 \\
(1.0)\end{array}$ & & & & & & & \\
\hline$\hat{\alpha}$ & $\begin{array}{c}0.19^{*} \\
(0.16)^{+}\end{array}$ & $\begin{array}{c}0.05 \\
(0.14)\end{array}$ & $\begin{array}{c}1.0 \\
(1.0)\end{array}$ & & & & & & \\
\hline$\alpha_{3}$ & $\begin{array}{c}0.24^{+4} \\
(0.16)^{+}\end{array}$ & $\begin{array}{c}0.05 \\
(0.14)\end{array}$ & $\begin{array}{c}0.96^{* *} \\
(1.0)^{* *}\end{array}$ & $\begin{array}{c}1.0 \\
(1.0)\end{array}$ & & & & & \\
\hline$\alpha_{a}$ & $\begin{array}{c}0.04 \\
(0.04)\end{array}$ & $\begin{array}{c}-0.01 \\
(-0.06)\end{array}$ & $\begin{array}{c}0.48^{* *} \\
(0.45)^{* *}\end{array}$ & $\begin{array}{c}0.47^{* *} \\
(0.45)^{* *}\end{array}$ & $\begin{array}{l}(1.0) \\
(1.0)\end{array}$ & & & & \\
\hline$S_{3}$ & $\begin{array}{c}0.37^{* *} \\
(0.33)^{* \star *}\end{array}$ & $\begin{array}{c}0.05 \\
(0.06)\end{array}$ & $\begin{array}{c}0.88^{* *} \\
(0.81)^{* *}\end{array}$ & $\begin{array}{c}0.87^{* *} \\
(0.81)^{* *}\end{array}$ & $\begin{array}{c}0.38^{* *} \\
(0.37)^{* *}\end{array}$ & $\begin{array}{c}1.0 \\
(1.0)\end{array}$ & & & \\
\hline$S_{a}$ & $\begin{array}{c}0.13 \\
(0.16)^{+}\end{array}$ & $\begin{array}{l}-0.02 \\
(-0.07)\end{array}$ & $\begin{array}{c}0.42^{* *} \\
(0.38)^{* *}\end{array}$ & $\begin{array}{c}0.38^{* *} \\
(0.38)^{* *}\end{array}$ & $\begin{array}{c}0.90^{* *} \\
(0.93)^{* *}\end{array}$ & $\begin{array}{c}0.45^{* *} \\
(0.45)^{* *}\end{array}$ & $\begin{array}{l}(1.0) \\
(1.0)\end{array}$ & & \\
\hline Type 1 & $\begin{array}{l}-0.03 \\
(-0.03)\end{array}$ & $\begin{array}{l}-0.05 \\
(-0.00)\end{array}$ & $\begin{array}{l}-0.13 \\
(-0.08)\end{array}$ & $\begin{array}{l}-0.12 \\
(-0.08)\end{array}$ & $\begin{array}{l}-0.38^{* *} \\
(-0.33)^{* *}\end{array}$ & $\begin{array}{l}-0.17^{+} \\
(-0.13)\end{array}$ & $\begin{array}{l}-0.38^{* *} \\
(-0.33)^{* *}\end{array}$ & $\begin{array}{c}1.0 \\
(1.0)\end{array}$ & \\
\hline Type 2 & $\begin{array}{c}-0.03 \\
(0.04)\end{array}$ & $\begin{array}{l}-0.08 \\
(-0.07)\end{array}$ & $\begin{array}{c}-0.09 \\
(-0.03)\end{array}$ & $\begin{array}{c}-0.08 \\
(-0.03)\end{array}$ & $\begin{array}{c}-0.12 \\
(-0.10)\end{array}$ & $\begin{array}{c}-0.09 \\
(-0.02)\end{array}$ & $\begin{array}{l}-0.10 \\
(-0.06)\end{array}$ & $\begin{array}{c}0.48^{* *} \\
(0.48)^{* *}\end{array}$ & $\begin{array}{c}1.00 \\
(1.00)\end{array}$ \\
\hline
\end{tabular}

${ }^{* *}$ significant at the $.01 \mathrm{level}^{*}{ }^{*}$ at the $.05 \mathrm{level} ;{ }^{+}$at the .10 level.

The significance tests are performed as follows:

(1) Under normality of the two underlying variables, and under $H_{0}: \rho=0$, we have $(r \sqrt{n-2}) /\left(\sqrt{1-r^{2}}\right) \sim t_{n-2}$, where $r$ is the ordinary correlation coefficient, and $n$, the number of observations (125 in this case).

(2) For $n>30, z=R \sqrt{n-1} \sim N(0,1)$, where $\mathrm{R}$ is the rank correlation coefficient. Note that this test does not require any distributional assumption. 
franchising found in the theoretical literature which suggest other factors one should control for in assessing the signaling explanation.

Each new franchisor may not need to distinguish itself from all other new franchisors. In other words, there might exist some variables that franchisees can observe that give them some information about franchisors' types. For example, the number of years in business prior to starting franchising may be related to or give information about the success a firm will achieve in franchising: in a sense, the firm has already established a reputation for itself in the market. In that case, a new franchisor need only distinguish itself from other new franchisors that have been in business for the same length of time. Thus one should control for the number of years a firm was in business prior to franchising in the empirical specification. Similarly, franchisors may only need to distinguish themselves from other franchisors getting involved in franchising at the same time they are. Because there are only a few possible years in which firms in this sample may have started franchising, i.e. from 1979 to 1984, dummy variables are used to control for this effect (with 1979 as the base case). Finally, assuming that the sector of operation is related to the future success of the firm in franchising, individual franchisors may only have to separate from other firms involved in the same type of business. This implies that sectoral dummy variables should also be used as control variables. The current sample of firms does not allow for a very detailed definition of sector, but I was able to distinguish the following 6 sectors: Automotive Services, Business Services, Construction and Maintenance, Restaurants, Non-food Retailing and Non-convenience Food Retailing. The remainder of the firms form a miscellaneous sector which serves as the base case in the empirical analyses.

As discussed in the literature, input mark-ups can be a substitute for royalties on sales, and hence for company operation of individual outlets in the present context. ${ }^{23}$ This would imply that franchisors have an additional signal at their disposal, which is the percentage of their franchisees' inputs they supply combined with the mark-up they take on the sale of such inputs. This new instrument would warrant empirical analysis on its own. Unfortunately, data on the value of franchisors' sales to franchisees, and a fortiori, data on the mark-ups taken on these sales, are unavailable for individual firms. Only aggregate data on the value of these sales per franchising

23 See for example Caves and Murphy (1975) on the equivalence between input mark-ups and royalty rates. 
sector are published each year in Franchising in the Economy. ${ }^{24}$ For this reason, rather than treat this variable as an additional signal, it is included in the regressions as a control variable.

Finally, many other theories beside signaling have been proposed to explain the existence of franchising. For example, Martin (1988) discusses an explanation based on risk-sharing, Mathewson and Winter (1985) focus on franchisee moral hazard, Rubin (1978), Lal (1990) and Bhattacharyya and Lafontaine (1992) argue that franchising is characterized by two-sided moral hazard, Hallagan (1978) gives a screening explanation for sharecropping that is easily applied to the case of franchising, and finally Caves and Murphy (1975) discuss the traditional explanation of franchising based on capital market imperfections. These theories imply that factors such as risk, franchisee moral hazard, franchisor moral hazard, and capital requirements could influence franchisors' choices of contract terms and contract mix. Consequently, one should control for these to the extent possible in testing for the signaling explanation. But quantifying such things as risk and moral hazard presents many challenges. First is the fact that it is not clear what the best measures for these are. And second are the constraints imposed by the type of data that are available.

Having said this, since most of the above factors are likely to be more homogeneous within sectors than across them, sectoral dummy variables will be useful in controlling for these as well. The dummy variables representing the year the firm became involved in franchising should also be useful in this respect. In addition, from Franchising in the Economy, one can get information concerning the rate of discontinuation of individual outlets for the appropriate years in the various franchising sectors defined earlier. Although these are aggregate sectoral rates, they provide some information concerning the degree of risk faced by potential franchisees. ${ }^{25}$

The Entrepreneur surveys include some estimate of the amount of capital required to open an outlet in each franchise chain. These estimates are necessarily imprecise: in fact, franchisors often give a range of values for this variable. In those

24 These are measured as the value of all sales from the franchisors to their franchisees as a proportion of all franchisee sales in the sector. The level of aggregation for this variable corresponds to the list of 14 D.O.C. sectors mentioned above. The aggregation is finer than that used to generate the sectoral dummy variables given that in the latter case, sectors with only a few observations were grouped with the miscellaneous category.

25 The level of aggregation for this variable corresponds to that of the input sales variable. 
cases, I use the average value assuming that it represents an estimate of the amount of capital necessary to open an average outlet.

In the case of franchisee moral hazard, measures of geographical dispersion have been used in the literature to capture differences in the cost of monitoring outlet performance (e.g. Brickley and Dark (1987) and Lafontaine (1992a)). In other words, it is assumed that a higher cost of monitoring makes franchisee moral hazard more problematic. The number of states in which a given chain has established outlets at the time of its initial franchise contract offering is the measure of geographical dispersion used here. It is available from the U.S. Department of Commerce's Handbook of Franchise Opportunities for 66 of the 125 firms in the sample.

Finally, for franchisor moral hazard, one measure of the importance of the franchisor's role in the business that is available for the same 66 firms from the same source is the amount of training (in days) that he provides to new franchisees. This is assumed to capture the amount of know-how that is being tranferred. In addition, the tradename is a central component of the franchise package sold by franchisors. Since the tradename is likely to become more valuable the longer a firm has been in business, and hence the more people are likely to have been exposed to it, the number of years during which the firm has been in business may also capture the importance of the franchisor's input. In this context, the effect of this variable on the royalty rates and the reliance on company-operated outlets would be the opposite of those suggested by the signaling theory: the more valuable the tradename, the more important the franchisor's role in the franchise and thus the more incentives one would want to give to the franchisor. These greater incentives can be achieved either through a higher royalty rate or through a greater proportion of company-owned outlets

\subsection{Regression Results}

Regression results for the various dependent variables over the sample of 125 franchisors are found in Tables 3, 4 and 5. Table 3 shows the results pertaining to the terms of the franchise contract, $r$ and $F$. Table 4 contains results relative to the case where all signaling is achieved through the contractual mix, $\alpha$, while Table 5 shows results pertaining to the stake $S$ the firm has in downstream operations. ${ }^{26}$ In all three tables, results obtained when growth is measured over the whole 5 or

\footnotetext{
26 Since they were used as control variables and they do not provide much insight to the problem
} 
more years (Type1) are presented first, followed by those obtained when growth is measured over only the last two of the same 5 years plus period (Type2).

In terms of the growth variable, which is the independent variable of interest here, all equations were estimated under both a linear and a quadratic form to allow for some curvature in the relationship. The two sets of results were equivalent so that only those based on the linear specification are presented in the tables. The maximum likelihood Tobit estimator is used instead of OLS because the dependent variables are bounded from below, and for each dependent variable, this boundary represents a binding constraint for at least a few observations. In fact, in the case of $\alpha_{a}$ and $S_{a}$, there are also observations at the upper limit of $100 \%$ so that a two-tail Tobit was used. ${ }^{27}$ Still, results obtained under OLS were very similar to the Tobit estimates.

The predictions from the signaling explanations, that the effect of franchisors' types on the royalty rate, or on the proportion of franchised stores, or on the franchisor's stake in downstream operations should be positive, are clearly not borne out in these tables either: In Table 3, one finds basically no relationship between the fees and the two measures of type. In Table 4, one finds that $\alpha$ relates negatively, not positively, to the measure of type, although in some cases the effect is not significantly different from zero. Results in Table 5 also indicate a negative rather than a negative relationship between the stake the franchisor initially has in downstream operations and his type. Finally, Table 6 shows the partial correlations (rank correlations in parentheses) between firms' reliance on company-ownership and their royalty rates, where the first column refers to the correlations holding Type1 constant, while the second column shows the same correlations when Type2 is held fixed. Conditional on the franchisor's type, these correlation coefficients should be negative if royalty rates and company-ownership are both used as signals. ${ }^{28}$ As can be seen from this table, where these correlations are in fact positive, there is no indication that franchisors trade-off royalty rates and the company-ownership of outlets.

at hand, the coefficients obtained for the six sectoral dummy variables are not reported in the tables.

27 In other words, I am assuming that the variables are distributed as truncated normals where the observations that would have been below zero are now found at zero (and those that would have been above $100 \%$ for $\alpha_{a}$ and $S_{a}$ are at one).

28 When the calculations were done holding fixed not only the type, but also the other variables used in the regressions, the correlation coefficients were also positive or nil. 
Table 3

Tobit Regression Results for Royalty Rates and Franchise Fees

\begin{tabular}{|c|c|c|c|c|}
\hline Variable & Royalty & Fran. Fee & Royalty & Fran. Fee \\
\hline Type1 & $\begin{array}{l}-0.16 \\
(-0.09)\end{array}$ & $\begin{array}{l}-3.00 \\
(-0.57)\end{array}$ & & \\
\hline Type2 & & & $\begin{array}{l}-1.05 \\
(-0.67)\end{array}$ & $\begin{array}{l}-0.65 \\
(-0.14)\end{array}$ \\
\hline Years in bus. & $\begin{array}{r}0.07^{*} \\
(2.06)\end{array}$ & $\begin{array}{c}0.03 \\
(0.32)\end{array}$ & $\begin{array}{c}0.07^{*} \\
(2.06)\end{array}$ & $\begin{array}{l}-0.04 \\
(-0.34)\end{array}$ \\
\hline Capital required & $\begin{array}{l}-0.20 \\
(-1.04)\end{array}$ & $\begin{array}{l}1.82^{* *} \\
(3.19)\end{array}$ & $\begin{array}{l}-0.21 \\
(-1.07)\end{array}$ & $\begin{array}{c}2.40^{* *} \\
(3.93)\end{array}$ \\
\hline Discontinuations & $\begin{array}{c}0.69^{+} \\
(1.69)\end{array}$ & $\begin{array}{l}-2.62^{*} \\
(-2.25)\end{array}$ & $\begin{array}{c}0.71^{+} \\
(1.74)\end{array}$ & $\begin{array}{l}-2.76^{*} \\
(-2.21)\end{array}$ \\
\hline Input Sales & $\begin{array}{c}0.15^{+} \\
(1.91)\end{array}$ & $\begin{array}{l}-0.13 \\
(-0.58)\end{array}$ & $\begin{array}{c}0.15^{+} \\
(1.94)\end{array}$ & $\begin{array}{l}-0.07 \\
(-0.30)\end{array}$ \\
\hline Franch. in 80 & $\begin{array}{c}0.88 \\
(0.92)\end{array}$ & $\begin{array}{r}6.73^{*} \\
(2.23)\end{array}$ & $\begin{array}{c}0.83 \\
(0.87)\end{array}$ & $\begin{array}{c}5.11^{+} \\
(1.74)\end{array}$ \\
\hline Franch. in 81 & $\begin{array}{l}-1.16 \\
(-1.14)\end{array}$ & $\begin{array}{c}4.87 \\
(1.61)\end{array}$ & $\begin{array}{l}-1.14 \\
(-1.13)\end{array}$ & $\begin{array}{c}4.42 \\
(1.42)\end{array}$ \\
\hline Franch. in 82 & $\begin{array}{l}2.94^{* *} \\
(2.86)\end{array}$ & $\begin{array}{c}2.79 \\
(0.96)\end{array}$ & $\begin{array}{c}2.88^{* *} \\
(2.83)\end{array}$ & $\begin{array}{c}3.32 \\
(1.07)\end{array}$ \\
\hline Franch. in 83 & $\begin{array}{c}1.29 \\
(1.22)\end{array}$ & $\begin{array}{l}-1.87 \\
(-0.63)\end{array}$ & $\begin{array}{l}1.26 \\
(1.22)\end{array}$ & $\begin{array}{l}-2.42 \\
(-0.76)\end{array}$ \\
\hline Franch. in 84 & $\begin{array}{l}-0.16 \\
(-0.11)\end{array}$ & $\begin{array}{c}5.28 \\
(1.30)\end{array}$ & $\begin{array}{l}-0.24 \\
(-0.17)\end{array}$ & $\begin{array}{r}7.85^{+} \\
(1.85)\end{array}$ \\
\hline Constant & $\begin{array}{c}5.13^{* *} \\
(3.21)\end{array}$ & $\begin{array}{l}18.03^{* *} \\
(4.05)\end{array}$ & $\begin{array}{c}5.14^{* *} \\
(3.24)\end{array}$ & $\begin{array}{l}17.76^{* *} \\
(3.65)\end{array}$ \\
\hline Limit Obs. & 4 & 6 & 4 & 6 \\
\hline $\begin{array}{l}\text { Non-Limit Obs. } \\
\text { LLF }\end{array}$ & $\begin{array}{c}121 \\
-320.41\end{array}$ & $\begin{array}{c}119 \\
-44672\end{array}$ & $\begin{array}{c}121 \\
-32012\end{array}$ & $\begin{array}{c}119 \\
-44970\end{array}$ \\
\hline Hetero Coef. $(\beta)$ & $\begin{array}{c}0.26 \\
(0.60)\end{array}$ & $\begin{array}{l}-1.17^{*} \\
(-2.55)\end{array}$ & $\begin{array}{c}-0.18 \\
(-0.34)\end{array}$ & $\begin{array}{l}-0.46 \\
(-1.22)\end{array}$ \\
\hline
\end{tabular}

Asymptotic t-statistics in parentheses.

Two-sided tests: ${ }^{* *}$ significant at the .01 level; $^{*}$ at the .05 level; ${ }^{+}$at the .10 level. 
Table 4

Tobit Regression Results for the Use of Company-Owned Outlets

\begin{tabular}{|c|c|c|c|c|c|c|}
\hline & $\hat{\alpha}$ & $\alpha_{3}$ & $\alpha_{a}$ & $\hat{\alpha}$ & $\alpha_{3}$ & $\alpha_{a}$ \\
\hline Type1 & $\begin{array}{l}-0.88 \\
(-1.46)\end{array}$ & $\begin{array}{l}-11.34 \\
(-1.22)\end{array}$ & $\begin{array}{l}-43.58^{* *} \\
(-3.23)\end{array}$ & & & \\
\hline Type2 & & & & $\begin{array}{l}-0.34 \\
(-0.64)\end{array}$ & $\begin{array}{l}-4.49 \\
(-0.56)\end{array}$ & $\begin{array}{l}-22.83^{+} \\
(-1.75)\end{array}$ \\
\hline Years in bus. & $\begin{array}{l}0.04^{* *} \\
(3.56)\end{array}$ & $\begin{array}{l}0.68^{* *} \\
(3.94)\end{array}$ & $\begin{array}{l}1.08^{* *} \\
(4.58)\end{array}$ & $\begin{array}{c}0.04^{* *} \\
(3.68)\end{array}$ & $\begin{array}{c}0.74^{* *} \\
(4.15)\end{array}$ & $\begin{array}{c}1.27^{* *} \\
(4.46)\end{array}$ \\
\hline Capital required & $\begin{array}{c}0.12^{+} \\
(1.96)\end{array}$ & $\begin{array}{l}1.79^{*} \\
(2.05)\end{array}$ & $\begin{array}{l}1.57 \\
(1.39)\end{array}$ & $\begin{array}{c}0.13^{+} \\
(1.92)\end{array}$ & $\begin{array}{r}2.08^{*} \\
(2.00)\end{array}$ & $\begin{array}{c}0.39 \\
(0.25)\end{array}$ \\
\hline Discontinuations & $\begin{array}{c}0.10 \\
(0.71)\end{array}$ & $\begin{array}{l}1.55 \\
(0.75)\end{array}$ & $\begin{array}{c}3.16 \\
(1.20)\end{array}$ & $\begin{array}{c}0.13 \\
(0.96)\end{array}$ & $\begin{array}{c}2.18 \\
(1.02)\end{array}$ & $\begin{array}{c}0.64 \\
(0.19)\end{array}$ \\
\hline Input Sales & $\begin{array}{c}0.05^{+} \\
(1.86)\end{array}$ & $\begin{array}{c}0.71^{+} \\
(1.83)\end{array}$ & $\begin{array}{c}0.58 \\
(1.18)\end{array}$ & $\begin{array}{r}0.06^{*} \\
(2.04)\end{array}$ & $\begin{array}{c}0.80^{+} \\
(1.89)\end{array}$ & $\begin{array}{c}0.48 \\
(0.75)\end{array}$ \\
\hline Franch. in 80 & $\begin{array}{l}-0.30 \\
(-0.92)\end{array}$ & $\begin{array}{l}-4.67 \\
(-0.93)\end{array}$ & $\begin{array}{l}-5.85 \\
(-0.85)\end{array}$ & $\begin{array}{l}-0.25 \\
(-0.74)\end{array}$ & $\begin{array}{l}-3.91 \\
(-0.77)\end{array}$ & $\begin{array}{l}-6.21 \\
(-0.77)\end{array}$ \\
\hline Franch. in 81 & $\begin{array}{l}-0.76^{*} \\
(-2.20)\end{array}$ & $\begin{array}{l}-10.78^{*} \\
(-2.08)\end{array}$ & $\begin{array}{l}-4.92 \\
(-0.68)\end{array}$ & $\begin{array}{l}-0.79^{*} \\
(-2.31)\end{array}$ & $\begin{array}{l}-11.34^{*} \\
(-2.17)\end{array}$ & $\begin{array}{c}1.80 \\
(0.21)\end{array}$ \\
\hline Franch. in 82 & $\begin{array}{c}0.02 \\
(0.05)\end{array}$ & $\begin{array}{l}-0.74 \\
(-0.15)\end{array}$ & $\begin{array}{l}-1.71 \\
(-0.27)\end{array}$ & $\begin{array}{c}0.04 \\
(0.11)\end{array}$ & $\begin{array}{c}0.08 \\
(0.02)\end{array}$ & $\begin{array}{l}-8.91 \\
(-1.08)\end{array}$ \\
\hline Franch. in 83 & $\begin{array}{c}0.48 \\
(1.49)\end{array}$ & $\begin{array}{c}8.89^{+} \\
(1.84)\end{array}$ & $\begin{array}{l}10.12 \\
(1.59)\end{array}$ & $\begin{array}{c}0.43 \\
(1.27)\end{array}$ & $\begin{array}{c}8.53 \\
(1.62)\end{array}$ & $\begin{array}{c}5.39 \\
(0.64)\end{array}$ \\
\hline Franch. in 84 & $\begin{array}{c}0.15 \\
(0.32)\end{array}$ & $\begin{array}{c}4.12 \\
(0.59)\end{array}$ & $\begin{array}{c}6.64 \\
(0.74)\end{array}$ & $\begin{array}{c}0.06 \\
(0.12)\end{array}$ & $\begin{array}{c}3.58 \\
(0.46)\end{array}$ & $\begin{array}{c}5.11 \\
(0.44)\end{array}$ \\
\hline Constant & $\begin{array}{c}0.56 \\
(1.06)\end{array}$ & $\begin{array}{c}5.86 \\
(0.74)\end{array}$ & $\begin{array}{l}-0.99 \\
(-0.10)\end{array}$ & $\begin{array}{c}0.39 \\
(0.74)\end{array}$ & $\begin{array}{c}2.68 \\
(0.33)\end{array}$ & $\begin{array}{c}8.97 \\
(0.69)\end{array}$ \\
\hline Lower Limit Obs. & 20 & 20 & 24 & 20 & 20 & 24 \\
\hline Upper Limit Obs. & 0 & 0 & 3 & 0 & 0 & 3 \\
\hline Non-Limit Obs. & 105 & 105 & 98 & 105 & 105 & 98 \\
\hline $\begin{array}{l}\mathrm{LLF} \\
(\beta)\end{array}$ & $\begin{array}{r}-175.37 \\
-1.13^{*} \\
(-2.37)\end{array}$ & $\begin{array}{c}-460.02 \\
-1.44^{* *} \\
(-2.92)\end{array}$ & $\begin{array}{c}-467.83 \\
-1.86^{* *} \\
(-4.03)\end{array}$ & $\begin{array}{c}-177.54 \\
-0.71^{+} \\
(-1.68)\end{array}$ & $\begin{array}{c}-463.37 \\
-0.74^{+} \\
(-1.83)\end{array}$ & $\begin{array}{r}-485.73 \\
-0.14 \\
(-0.25)\end{array}$ \\
\hline
\end{tabular}

Asymptotic t-statistics in parentheses.

Two-sided tests: ${ }^{* *}$ significant at the .01 level; $^{*}$ at the .05 level; ${ }^{+}$at the .10 level. 
Table 5

Tobit Regression Results for the Stake of the Franchisor in Downstream Operations

\begin{tabular}{|c|c|c|c|c|}
\hline Variable & $S_{3}$ & $S_{a}$ & $S_{3}$ & $S_{a}$ \\
\hline Type1 & $\begin{array}{l}-19.65^{*} \\
(-2.19)\end{array}$ & $\begin{array}{l}-50.96^{* *} \\
(-3.85)\end{array}$ & & \\
\hline Type2 & & & $\begin{array}{l}-9.15 \\
(-1.19)\end{array}$ & $\begin{array}{l}-16.25 \\
(-1.27)\end{array}$ \\
\hline Years in bus. & $\begin{array}{c}0.66^{* *} \\
(3.73)\end{array}$ & $\begin{array}{c}1.09^{* *} \\
(4.24)\end{array}$ & $\begin{array}{c}0.70^{* *} \\
(3.93)\end{array}$ & $\begin{array}{r}1.28^{*} \\
(4.47)\end{array}$ \\
\hline Capital required & $\begin{array}{r}2.13^{*} \\
(2.31)\end{array}$ & $\begin{array}{c}1.56 \\
(1.21)\end{array}$ & $\begin{array}{r}2.09^{*} \\
(1.99)\end{array}$ & $\begin{array}{c}0.67 \\
(0.42)\end{array}$ \\
\hline Discontinuations & $\begin{array}{c}2.31 \\
(1.14)\end{array}$ & $\begin{array}{c}2.50 \\
(0.89)\end{array}$ & $\begin{array}{c}2.97 \\
(1.44)\end{array}$ & $\begin{array}{c}1.24 \\
(0.37)\end{array}$ \\
\hline Input Sales & $\begin{array}{c}0.28 \\
(0.74)\end{array}$ & $\begin{array}{c}0.39 \\
(0.72)\end{array}$ & $\begin{array}{c}0.43 \\
(1.08)\end{array}$ & $\begin{array}{c}0.63 \\
(1.01)\end{array}$ \\
\hline Franch. in 80 & $\begin{array}{l}-4.70 \\
(-0.93)\end{array}$ & $\begin{array}{l}-5.41 \\
(-0.75)\end{array}$ & $\begin{array}{l}-4.34 \\
(-0.86)\end{array}$ & $\begin{array}{l}-5.64 \\
(-0.72)\end{array}$ \\
\hline Franch. in 81 & $\begin{array}{l}-13.66^{* *} \\
(-2.63)\end{array}$ & $\begin{array}{l}-9.08 \\
(-1.20)\end{array}$ & $\begin{array}{l}-14.98^{* *} \\
(-2.91)\end{array}$ & $\begin{array}{l}-5.47 \\
(-0.66)\end{array}$ \\
\hline Franch. in 82 & $\begin{array}{l}-1.29 \\
(-0.26)\end{array}$ & $\begin{array}{l}-3.00 \\
(-0.43)\end{array}$ & $\begin{array}{l}-2.27 \\
(-0.44)\end{array}$ & $\begin{array}{l}-10.00 \\
(-1.22)\end{array}$ \\
\hline Franch. in 83 & $\begin{array}{r}9.43^{+} \\
(1.87)\end{array}$ & $\begin{array}{l}13.08^{+} \\
(1.85)\end{array}$ & $\begin{array}{c}8.73 \\
(1.62)\end{array}$ & $\begin{array}{c}6.08 \\
(0.72)\end{array}$ \\
\hline Franch. in 84 & $\begin{array}{l}-2.88 \\
(-0.41)\end{array}$ & $\begin{array}{l}-0.05 \\
(-0.05)\end{array}$ & $\begin{array}{l}-3.82 \\
(-0.51)\end{array}$ & $\begin{array}{l}-0.90 \\
(-0.08)\end{array}$ \\
\hline Constant & $\begin{array}{l}20.14^{*} \\
(2.57)\end{array}$ & $\begin{array}{l}19.36^{+} \\
(1.81)\end{array}$ & $\begin{array}{l}16.92^{*} \\
(2.15)\end{array}$ & $\begin{array}{l}23.60^{+} \\
(1.87)\end{array}$ \\
\hline Lower Limit Obs. & 3 & 4 & 3 & 4 \\
\hline Upper Limit Obs. & 0 & 3 & 0 & 3 \\
\hline Non-Limit Obs. & 122 & 118 & 122 & 118 \\
\hline LLF & -520.97 & -549.99 & -524.41 & -564.33 \\
\hline Hetero Coef. $(\beta)$ & $\begin{array}{l}-1.13^{* *} \\
(-2.83)\end{array}$ & $\begin{array}{l}-1.37^{* *} \\
(-3.21)\end{array}$ & $\begin{array}{c}-0.67^{+} \\
(-1.78)\end{array}$ & $\begin{array}{c}-0.03 \\
(-0.06)\end{array}$ \\
\hline
\end{tabular}

Asymptotic t-statistics in parentheses.

Two-sided tests: ${ }^{* *}$ significant at the .01 level; ${ }^{*}$ at the .05 level; ${ }^{+}$at the .10 level. 
Table 6

\section{Correlation and Rank Correlation Coefficients}

$\begin{array}{ccc} & \text { Type 1 } & \text { Type 2 } \\ \rho(\mathrm{r}, \hat{\alpha} \mid T) & 0.19^{*} & 0.19^{*} \\ & (0.17)^{+} & (0.16)^{+} \\ \rho\left(\mathrm{r}, \alpha_{3} \mid T\right) & 0.23^{* *} & 0.23^{* *} \\ & (0.18)^{*} & (0.17)^{+} \\ \rho\left(\mathrm{r}, \alpha_{a} \mid T\right) & 0.04 & 0.04 \\ & (0.05) & (0.06)\end{array}$

See bottom of Table 2 for footnotes.

Since the data are cross-sectional, all equations in Tables 3,4 and 5 were tested for heteroscedasticity, and corrected when appropriate, using the method suggested by Maddala (1983). The functional form used for $\sigma$ was $\sigma=\exp \left(\alpha+\beta \cdot\right.$ Type) ${ }^{29}$ The test for heteroscedasticity then reduces to a test of the significance of $\beta$. The value of $\beta$ and its asymptotic t-ratio are reported for each equation at the bottom of the tables. Corrections were done whenever the $\beta$ coefficient was found to be significant at a level of .10 or better. Also tests were done to determine whether multiplicative sectoral dummies should be included in the regressions. In general, these dummies were not found to be significant and hence they were excluded from the analyses. ${ }^{30}$

The measures of franchisee and franchisor moral hazard, respectively the number of states in which a franchisor has established outlets and the number of days of training for new franchisees, are available for only 66 of the 125 franchisors. As a result, they are not included in the regressions presented in Tables 3,4 and 5. To determine how sensitive the results might be to the exclusion of these variables, the regressions were reestimated with these two variables for the subsample of 66 firms for which this information was available. The results are found in Appendix B, in

\footnotetext{
29 I am grateful to Stephen Donald for suggesting this functional form.

30 These results are available from the author upon request.
} 
Tables 3A, 4A and 5A. These two variables have a significant effect only on the actual proportion of company-owned outlets and the actual stake the firm has in downstream operations 3 or 4 years after it becomes involved in franchising. For all other dependent variables, a joint test that their coefficients are zero could not be rejected. And in no case does their inclusion really affect the results relative to the measures of type. In that sense, Tables 3,4 and 5 provide a meaningful set of results despite the absence of these control variables in the regressions.

Finally it is worth noting that in all tables, the input sales variable has either no significant effect or it has a positive effect on royalty rates, franchise fees and the use of company-ownership. None of these effects is consistent with the notion that these sales are used as an alternative source of revenues by franchisors. One possible explanation for these results would be that these inputs are not sold at a mark-up so that they do not generate additional revenues to the franchisor. There are efficiency arguments to be made for franchisors opting for royalty rates over input mark-ups: if the technology downstream is not one of fixed proportions, franchisees will substitute away from inputs they must buy at a relatively higher price. Royalty rates, on the other hand, will not lead to such distortions in franchisees' input buying behavior. ${ }^{31}$

As was mentioned above, in a signaling framework, the number of years in business prior to franchising could provide potential franchisees with information about the type of the firm, with the franchisor that has been in business for a longer period being more likely to be a high-value franchisor. In that case, the high type franchisor would not need to signal his type through royalties or company-owned outlets. This would imply that the number of years in business would have a negative effect on royalties and the use of company-owned outlets, and a positive one on the franchise fee. But in all tables, one typically finds a positive and significant relationship between the number of years in business prior to franchising and the use of royalties and company-ownership. Hence results relative to this variable are also inconsistent with the signaling explanation for franchising.

Interestingly, these results are the opposite of those reported for the same variable in Lafontaine (1992a). I believe this difference is largely attributable to the different sample of firms used here, namely to the fact that the franchisors included here are

31 Note that in Traditional franchising, where input sales at a mark-up are the typical way in which franchisors receive profits from downstream operations, the technology is usually one of fixed proportions. 
all just beginning to franchise. As a result, the longer they have been in business, the more time they have had to develop their business format, leading them potentially to ask for higher royalty payments. Also, these "older" firms are more likely to have opened a larger number of outlets, outlets that by definition are company-owned. ${ }^{32}$ In either case, these results are supportive of the interpretation of years in business as a measure of the value of the tradename in the context of franchisor moral hazard.

Finally, though this is not the focus of this paper, it is worth saying a few words about the results obtained for the other control variables in the regressions, and how these results relate to the various theories mentioned above. First, the risk variable has a positive effect (though generally not an effect that is significantly different from 0 ) on the royalty rates and the use of company-ownership, and a negative effect on the franchise fees. These results, which to some extent support the notion that franchisors provide insurance to their franchisees, are consistent with results from Banerji and Simon (1991), but opposite to those found in Martin (1988) and Lafontaine (1992a). Why this is remains unclear at this point.

Second, the amount of capital required increases the franchise fee and franchisor's tendency to rely on company-operated stores. These results are equivalent to those reported in Lafontaine (1992a). While the first effect is consistent with the notion that franchisors use franchising as a source of capital, the second effect is not. Brickley and Dark (1987) argue that this second effect can be explained by the increased contracting costs related to higher capital requirements: when the franchisee must invest heavily in firm-specific assets, he faces more risk and hence requires a higher level of compensation. This would make franchising less attractive for firms whose concepts call for large capital expenditures. However, one way to reduce the risk to the franchisee is to ask for a smaller franchise fee. Yet as we just saw, franchisors do not do this. Instead, they increase the franchise fee when the capital required to open an outlet goes up.

Finally, from the tables in the appendix, we see that the measures of franchisee and franchisor moral hazard rarely have a significant effect on the terms of the contract or on the contract mix. The only variables that are significantly affected by these are

32 In other words, in the present paper, the number of years in business captures the effect that the "\% time not franchising" variable captured in Lafontaine (1992b), i.e. some notion of the value of the business format. Looking at the variables in this way, the results obtained in the two papers are completely consistent. 
the actual proportion of company-owned stores and the actual stake the firm has in downstream operations 3 or 4 years after it begins franchising. And those effects are consistent with predictions from a double-sided moral hazard model.

\section{Discussion}

The results presented above do not support the notion that franchisors use the terms of their franchise contracts, royalty rates and franchise fees, or their capacity to operate outlets directly, or a combination of the two, to give information to potential franchisees about the value of their franchise. While I believe that these results in themselves are convincing, two other patterns found in the data further support this conclusion.

First, the terms of the contracts were found not to vary significantly over the five or more years separating the two observations on each firm. Banerji and Simon (1991) and survey results in Lafontaine (1992b) also suggest that contract terms (and even the contract mix) tend to be fairly stable over time. As noted in Gallini and Lutz (1992), in the context of a signaling explanation, one would expect the royalty rates to decrease, and the franchise fees to increase over time since information about franchisors' types becomes known and the need to signal disappears. Yet the data do not show this pattern.

Second, if an established reputation reduces a franchisor's need to signal his type, the number of years in business prior to franchising should have a negative effect on royalty rates and on the use of company-owned outlets. Instead, the observed positive effect is supportive of the idea first proposed by Rubin (1978) that moral hazard on the part of the franchisor is an important consideration in franchising.

Finally, the existing empirical evidence on franchising is consistent with the lack of support found here for the signaling model in the sense that it suggests that incentives issues and monitoring costs are a central issue in franchising: Brickley and Dark (1987), Norton (1988) and Minkler (1991) have found results suggesting that franchisee moral hazard is an important consideration in the franchise versus companyown decision. Furthermore, Lafontaine (1992a) finds that the terms of the contract, as well as the decision to franchise or operate directly, are influenced by factors related to both the franchisees and the franchisors' incentives. Finally, as reported earlier, survey results in Lafontaine (1992b) suggest that the main advantages of company- 
operated outlets to franchisors were not related to signaling, but rather to the fact that such outlets were used as laboratories for new product development and R\&D, as well as for the training of new franchisees and managers, the development of marketing and planning activities, etc. ${ }^{33}$ In the same survey, the main reasons given by franchisors to use royalties based on sales rather than a fixed amount per time period were that this allowed both the franchisor and the franchisee to share in the success (or failure) of the outlet, that they give opportunities for both firms to grow together, and that they provide incentives to the franchisor as well as the franchisee. Again these point to incentive issues as the basis for the existence of royalties in franchising.

On the other hand, Gallini and Lutz (1992) present some empirical evidence suggesting that indeed the proportion of company-owned stores decreases in franchised chains as the number of years since they began franchising increases. Similar results are found in Lafontaine (1992a) and Martin (1988). These patterns are consistent with the signaling hypothesis, i.e. with the notion that firms initially use companyownership as a signal of their quality, and subsequently reduce their reliance on this signal as information about their value becomes known. However, as some of the discussion in Section 3 suggests, these patterns should be interpreted with care. Because they are interested in signaling, the sample of firms considered by Gallini and Lutz, like the one considered here, contains only relatively new firms. But by definition, at the time they start franchising, these firms are $100 \%$ company-owned. At that point in time, any franchising activity on the part of the firm will lead to a reduction in the proportion of company-owned outlets. As a result, it is difficult to infer anything from the observed evolution of the proportion of company-owned stores in the early years of a franchise chain. In fact, because their samples also contained a number of new franchisors, this problem is likely to explain at least in part the results obtained in Lafontaine (1992a) as well as Martin (1988). Overall then, one must conclude that the data are not consistent with a signaling explanation of franchising.

\section{Conclusion}

The goal of this paper was to examine empirically whether signaling can explain the use of royalties and company-ownership of outlets in franchising. My findings

33 Note that such outlets are likely to be located close to the firm's headquarters for reasons that have to do with their accessibility. This however does not rule out the possibility that the proximity also serves to alleviate monitoring problems. 
suggest that it cannot. All this is not to say that there is no asymmetric information about the value of franchises, for there clearly is. Gallini and Lutz (1992) document this fact very well. But there are two main problems with the signaling explanation in the context of long term relationships such as the ones involved here. ${ }^{34}$

First, signaling through the terms of the franchise contract implies inefficiencies and a lack of flexibility for the duration of this contract. Hence it would very costly. Put differently, if royalty rates and franchise fees were used to provide information to franchisees about the fundamental value of the franchise, and given that franchisors get to choose the length of their contract, one would not expect the contracts to be set for such long periods. Similarly, signaling through the contract mix can be very costly. In Gallini and Lutz (1992), it involves a suboptimal effort level to be put into the development of a particular location, the effect of which are non-reversible. Without such high costs however, signaling through the contract mix would not be credible: firms could modify their contract mix in a significant way once a number of contracts were signed. In general, the issue here is that there likely exist more efficient signals of franchisor quality. For example, membership in the International Franchise Association is conditional on franchisors meeting certain criteria for admission and on their respecting a particular code of ethics. If the admission criteria for this association were discriminating enough, then simply belonging to this association might be taken as a credible way to convey information. And indeed from the finance literature, one finds evidence that such alternatives exist and that they are used: Balvers, McDonald and Miller (1988) found that firms' underpricing of new issues (the standard signal) is significantly reduced by an appropriate choice of investment banker and auditor. The latter firms' reputations convey information about the value of the stock such that the issuing firm does not need to underprice the offer as much.

Second, and more importantly, the kind of information the franchisee is seeking when considering buying a franchise is not limited to how good the franchisor is now, but includes information about how good he is likely to be in the future. To the extent that the future worth of the franchise will depend on the franchisor's future behavior, the franchisee will be looking for guarantees in the contract about this future behavior. In this context, royalties on sales, and possibly the company-ownership of outlets, are used not as signals of an exogenously given and fixed franchisor value, but rather as

34 According to the Department of Commerce, franchise contracts last an average of about 15 years. See Franchising in the Economy, 1988. 
incentive mechanisms that reassure the franchisee as to the future behavior of the franchisor, and therefore as to the future value of the franchise. (See Rubin (1978), Lal (1990). and Bhattacharyya and Lafontaine (1992) for this type of argument, and Lafontaine (1992a) for empirical evidence supporting it.)

More generally, the negative result obtained in this paper is interesting not only in what it tells us about franchising, but also in what it reveals about the circumstances under which signaling, and information asymmetries in general, may or may not provide appropriate explanations for particular phenomena. Specifically, the results in this paper suggest that even if there is evidence of asymmetric information, signaling cannot be used to explain the terms by which long term relationships are governed. This is because the longer the relationship is, a) the more likely it is that alternative cheaper signals will exist, and more importantly b) the more likely it is that the required information is not exogenously given and fixed, but rather is a function of the future behavior of the informed party. (See Ippolito (1990) for a similar argument concerning signaling in the context of consumer durables.) Hence one must look elsewhere, towards monitoring costs and other organizational efficiency arguments, to explain the nature and use of various types of long-term contractual arrangements. 


\section{REFERENCES}

Akerlof, G., (1970), "The Market for 'Lemons': Qualitative Uncertainty and the Market Mechanism", Quarterly Journal of Economics, 89, 448-500.

Balvers, R.J., B. McDonald and R.E. Miller (1988), "Underpricing of New Issues and the Choice of Auditor as a Signal of Investment Banker Reputation", The Accounting Review, 63, 605-622.

Banerji, S. and C. Simon, (1991), "Franchising Vs. Ownership: A Contracting Explanation", mimeo, University of Chicago.

Bhattacharyya, S. and F. Lafontaine, (1992), Double Moral Hazard and Franchising, mimeo, Carnegie Mellon University.

Bond, R.E., (1989), The Source Book of Franchise Opportunities, Richard D. Irwin Publishing Co.

Brickley, J.A. and F.H. Dark, (1987), "The Choice of Organizational Form: The Case of Franchising", Journal of Financial Economics, 18, 401-420.

Card, D., (1988), Strikes and Wages: A Test of a Signaling Model, Working Paper No. 2550, NBER.

Caves, Richard E. and William F. Murphy II, (1976), "Franchising: Firms, Markets, and Intangible Assets", Southern Economic Journal, 42, April, 572-586.

Conference Board (The) (1971), Franchised Distribution, Conference Board Report No. 523, New York, N.Y.

Cooper, R. and T.W. Ross (1984), "Prices, Product Qualities and Asymmetric Information: The Competitive Case", Review of Economic Studies, 51, 197-207.

- (1985), "Product Warranties and Double Moral Hazard", Rand Journal of Economics, 16, 103-113.

Crocker, K.C., (1983), "Vertical Integration and the Strategic Use of Private Information", The Bell Journal of Economics, 14, 236-248.

Curry D.J. and Riesz P.C. (1988), "Prices and Price/Quality Relationships: A Longitudinal Analysis", Journal of Marketing, 52, 36-51.

Desai P. and Srinivasan, K., (1990), A Channel Management Issue: New Franchising in the Presence of Two-Sided Information Asymmetry, mimeo, Carnegie Mellon University, August.

Downes, D.H. and Heinkel, R.,(1982) "Signaling and the Valuation of Unseasoned New Issues", The Journal of Finance, 37, 1-10.

Entrepreneur Magazine, Annual Franchise 500, Feb. 1981; Jan. 1982; Jan. 1983; Jan. 1984; Jan. 1985; Jan. 1986; Jan. 1987; Jan. 1988; Jan. 1989. 
Gallini, N. and B. Wright (1987), Technology Transfer Under Asymmetric Information, mimeo.

Gallini, N. and B. Wright (1990), "Technology Transfer Under Asymmetric Information", The Rand Journal of Economics, 21, 147-160.

Gallini, N. and N. Lutz (1992), "Dual Distribution and Royalty Fees in Franchising", Journal of Law, Economics, \& Organization, forthcoming.

Garvin (1983), "Quality on the Line", Harvard Business Review, Sept.-Oct. 1983, 65-75.

Gerner, J. and W.K. Bryant, (1981), "Appliance Warranties as a Market Signal?", Journal of Consumer Affairs, 15, 75-86.

Gerstner, E., (1985), "Do higher Prices Signal Higher Quality?", Journal of Marketing Research, 22, 209-215.

Grossman, S. (1981), "The Informational Role of Warranties and Private Disclosure about Product Quality", Journal of Law and Economics, 24, 461-483.

Hadfield, G.K., (1990), "Problematic Relations: Franchising and the Law of Incomplete Contracts", Stanford Law Review, 927-992.

Hallagan, W., (1978), "Self-Selection by Contractual Choice and the Theory of Sharecropping", Bell Journal of Economics, 9, 344-354.

Info Press Inc., The Franchise Annual, 1986;1987, edited by E. L. Dixon.

Ippolito, P.M., (1990), "Bonding and Nonbonding Signals of Product Quality", Journal of Business, 63, 41-60.

Jovanovic, B., (1982), "Selection and the Evolution of Industry", Econometrica, 50, 649-670.

Kaufmann, P.J. and F. Lafontaine, (1992), "Costs of Control: The Source of Economic Rents for McDonald's Franchisees", University of Michigan School of Business Administration Working Paper.

Kihlstrom R.E. and M.H. Riordan (1984), "Advertising as a Signal", Journal of Political Economy, 92, 427-450.

Kirmani, A. and P. Wright (1989), "Money Talks: Perceived Advertising Expense and Expected Product Quality", Journal of Consumer Research, 16, 344-353.

Lafontaine, F., (1992a), "Contract Theory and Franchising: Some Empirical Results", Rand Journal of Economics, Summer.

Lafontaine, F. (1992b) "How and Why do Franchisors do What They do: A Survey Report", in Franchising: Passport for Growth \& World of Opportunity, P. Kaufmann Ed., Sixth Annual Proceedings of the Society of Franchising, International Center for Franchise Studies, University of Nebraska. 
Lal, R., (1990), "Improving Channel Coordination through Franchising," Marketing Science, 9, 299-318.

Leland H.E. and D.H. Pyle (1977), "Informational Asymmetries, Financial Structure and Financial Intermediation", The Journal of Finance, 32, 371-387.

Lutz, N.A. (1989), "Warranties as Signals under Consumer Moral Hazard", Rand Journal of Economics, 20, 239-255.

Martin, R.E., (1988), "Franchising and Risk Management", The American Economic Review,78, 954-968.

Mathewson. G.F. and R.A. Winter, (1985), "The Economics of Franchise Contracts", Journal of Law and Economics, 28, October, 503-526.

Matthews, S. and J. Moore, (1987), "Monopoly Provision of Quality and Warranties: An Exploration in the Theory of MultiDimensional Screening", Econometrica, 55, 441-467.

McAfee, R.P. and M. Schwartz, (1992), "Multilateral Vertical Contracting: Opportunism, Nondiscrimination, and Exclusivity", Georgetown University Department of Economics Discussion Paper.

Milgrom, P. (1981), "Good News and Bad News: Representation Theorems and Applications", Bell Journal of Economics, 12, 380-391.

Milgrom, P. and J. Roberts (1986), "Price and Advertising Signals of Product Quality", Journal of Political Economy, 94, 796-821.

Minkler, A.P., (1990), "An Empirical Analysis of a Firm's Decision to Franchise", Economics Letters, 34, 77-82.

Norton, S.W., (1988), "An Empirical Look at Franchising as an Organizational Form", Journal of Business, 61, 197-217.

Pittman, R., (1990), Specific Investments, Contracts, and Opportunism: The Evolution of Railroad Sidetrack Agreements, Economic Analysis Group Discussion Paper, U.S. Department of Justice, Antitrust Division.

Priest, G.L., (1981), "A Theory of the Consumer Product Warranty", Yale Law Journal, Vol. 90, 1297-1352.

Rubin, H.,(1978), "The Theory of the Firm and the Structure of the Franchise Contract", Journal of Law and Economics, 21, April, 223-233.

Spence, M. (1973), "Job Market Signaling", Quarterly Journal of Economics, 87, 355-374.

Spence, M. (1974), Market Signaling: Informational Transfer in Hiring and Related Screening Process, Harvard University Press, Cambridge. 
Stiglitz, J.E., (1974), "Incentives and Risk-Sharing in Sharecropping", Review of Economic Studies, 41, 219-255.

Tellis G.J. and B. Wernerfelt (1987), "Competitive Price and Quality under Asymmetric Information", Marketing Science, 6, 240-253.

Tirole, J. (1988), The Theory of Industrial Organization, MIT Press, 174-181 and $444-453$.

Tracy, J. (1987), "An Empirical Test of an Asymmetric Information Model of Strikes", Journal of Labor Economics, 5, 149-173.

U.S. Department of Commerce, Franchise Opportunities Handbook, compiled by Andrew Kostecka, Oct. 1985; Nov. 1986; Jan. 1988.

U.S. Department of Commerce, Franchising in the Economy, prepared by Andrew Kostecka, various years.

Venture, The Franchise 100, Nov. 1986, Dec.1988.

Vermaelen, T. (1981), "Common Stock Repurchases and Market Signalling", Journal of Financial Economics, 9, 139-183.

White, H., (1980), "A Heteroscedasticity-Consistent Covariance Matrix Estimator and a Direct Test of Heteroscedasticity", Econometrica, 48, 817-838.

Wiener, J.L., (1985), "Are Warranties Accurate Signals of Product Reliability?", Journal of Consumer Research, 12, 245-250.

Wilson, R. (1985), "Multi-dimensional signaling", Economics Letters, 19, 17-21.

Wolinsky, A. (1983), "Prices as Signals of Product Quality", Review of Economic Studies, 50, 647-658. 


\section{Appendix A}

This appendix discusses more precisely the signaling explanation in the context of franchising. The first part is concerned with the more basic model from Gallini and Wright (1987) and (1990), Tirole (1988), and Desai and Srinivasan (1990), where all signaling is achieved through the terms of the franchise contract, namely royalty rate and franchise fee only. The second model, based on Gallini and Lutz (1992), allows franchisors to signal their types through their contract mix as well as the terms of their contracts. Since pooling equilibria can be ruled out by an appropriate choice of refinement, and, more importantly, since only separating equilibria imply differences in firms' behavior that can be tested empirically, only separating equilibria are discussed here.

\subsection{Signaling Though the Terms of the Franchise Contract}

Consider a risk-neutral franchisor with no established reputation. He obtains a tradename of high (h) or low (l) value from a common knowledge probability distribution, where the probability of getting a low value tradename is $\theta$. Inverse demand at the retail level is given by $p=p(q, T)$ where $T$ stands for the value of the tradename. Alternatively, demand may be written as $p^{h}(q)$ and $p^{l}(q)$ with $p^{h}(q) \geq p^{l}(q)$ for all $q \geq 0$.

A competitive market for potential franchisees, who are also risk neutral, is assumed to exist. The franchise contract $c=(r, F)$ stipulates a royalty rate on sales, $r \in[0,1)$ and an upfront fee, $F \geq 0$, such that the franchisor's revenues from a franchised outlet over the duration of the contract are given by

$$
R(r, F)=r \cdot p^{i}\left(q^{i}(c)\right) q^{i}(c)+F \quad i=h, l
$$

where $q^{i}(c)$ is the franchisee's choice of output over the duration of the contract, given that the contract is $c$ and that the franchisor is of type $i$. The franchisee is assumed to learn the franchisor's type after signing the contract but before choosing her action. It is assumed that the contract cannot be renegotiated after the franchisee has observed the franchisor's type. ${ }^{35}$ The franchisee's profits before payment of the

35 It must also be that the value of the tradename, although observed ex post by both parties, is not verifiable by a third party. Otherwise, the optimal ex ante contract would simply have to be made contingent on this value to achieve the first-best. 
franchise fee are

$$
\pi^{i}\left(q^{i}\right)=(1-r) p^{i}\left(q^{i}(c)\right) q^{i}(c)-K \quad i=h, l
$$

where $K$ stands for the set-up costs of the franchisee which are assumed the same whether the franchisor's type is high or low. For notational simplicity, marginal costs at the outlet level are assumed to be $0 . \pi^{i}$ is assumed strictly concave in $q^{i}$.

Without asymmetric information, the contract that would maximize the franchisor's profits would have each type extracting all of the franchisee's profits through the fixed fee $F$. Any $r>0$ would lead to a suboptimal quantity being chosen by the franchisee since the royalty rate increases marginal cost (or reduces marginal revenue) downstream. ${ }^{36}$ With a fixed fee contract, the franchisee would be asked to pay a transfer price equal to the franchisor's marginal cost, and hence he would choose the optimal $q^{i}$. The franchise contracts would be given by $c^{h}=\left(0, \Pi^{h}\right)$ and $c^{b}=\left(0, \Pi^{l}\right)$ for the high and low-value franchises, where $\Pi^{h}$ and $\Pi^{l}$ are the first-best profits of the outlets, before payment of the fixed fee, when the tradenames are high and low-value respectively.

With asymmetric information, in a separating equilibrium, both types are revealed. Given this, the low type's optimal contract is $c^{d}$ by definition. But the franchisor with the good tradename cannot offer $c^{h}$ since the franchisor with a lowvalue tradename would also choose $c^{h}$ and separation would fail. The "good" franchisor must offer a contract $\hat{c}=\left(\hat{r}>0, \hat{F}<\Pi^{h}\right)$ that satisfies the franchisee's participation constraint and is less profitable than $c^{l}$ for the low-value franchisor. A necessary condition for a set of separating contracts to exist in this context is that $d\left(R_{r}(r, T)\right) / d T>0$, where $R_{r}$ is the derivative of the franchisor's revenues $R$ with respect to the royalty rate $r$.

In order for the contract chosen by the high-type to be unappealing to the low type, it must be that

$$
\hat{r} \cdot p^{l}\left(q^{l}(\hat{c})\right) q^{l}(\hat{c})+\hat{F} \leq \max \left[0, \Pi^{l}\right] .
$$

36 This is the standard double-marginalization argument. It might be argued that in an oligopolistic setting, positive royalty rates are beneficial to franchisors since they reduce output and hence bring firms closer to the collusive outcome. However, after franchisors have signed their contracts with franchisees, they extract their profits from the sales levels of their franchisees. As a result, they have no incentive to increase profits at the expense of lower sales. 
Notice that the low-value franchisor's revenues under $\hat{c}$ are necessarily non-negative, since the franchise fee $\hat{F}$ is assumed to be non-negative and sales are by definition non-negative. Consequently, $\Pi^{l}$ must be greater than 0 for a separating equilibrium to exist. ${ }^{37}$ Hence, (6.3) may be rewritten as

$$
0 \leq \hat{r} \cdot \hat{p}^{l} \hat{q}^{l}+\hat{F} \leq \Pi^{l}
$$

where $\hat{p}^{l}=p^{l}\left(q^{l}(\hat{c})\right)$ and $\hat{q}^{l}=q^{l}(\hat{c})$. If this condition is met, then the pair of contracts $\left(\hat{c}, c^{b}\right)$ signals perfectly. The franchisee, knowing that the firm offering $\hat{c}$ has a highvalue tradename, assigns an ex-post probability $g(\hat{c})=1$ to the franchisor being a good type and accepts the contract if $\hat{F} \leq(1-\hat{r}) \hat{p}^{h} \hat{q}^{h}-K$. After eliminating dominated strategies ${ }^{38}$ the unique separating equilibrium contract for the high-value franchisor, $c^{*}=\left(r^{*}, F^{*}\right)$, solves

$$
\max _{r, F}\left[r \cdot p^{h}\left(q^{h}(c)\right) q^{h}(c)+F\right]
$$

subject to

$$
r \cdot p^{l}\left(q^{l}(c)\right) \cdot q^{l}(c)+F=\Pi^{l}
$$

and

$$
(1-r) p^{h}\left(q^{h}(c)\right) \cdot q^{h}(c)-K-F \geq 0 .
$$

Notice that from (6.6) and the fact that royalty payments are non-negative, the franchise fee $F^{*}$ in $c^{*}$ can never be greater than $\Pi^{l} .39$

The solution to the above program gives two schedules, one for $r$ and one for $F$, as functions of the franchisor's type $T$ : for $r$, we find that $r^{h}>r^{l}=0$, and for $F$, that $F^{h}<F^{l}=\Pi^{l}$. Extending to a continuum of types, the schedule for $r$ would be increasing in $T$, with the absolute lowest choosing $r=0$, while the schedule for $F$ would be decreasing in $T$.

37 In other words, low-value franchises must still be profitable otherwise separation would never occur. As a result, an empirical test of this model cannot be based on a definition of types that is derived from a notion of survival.

38 See Tirole (1988) chapter 11 for an introduction to the refinements literature, and Cho and Kreps (1987) and the references therein for more details.

39 Also, the franchisor with type $h$ must prefer $c^{*}$ to $c^{l}$. But that is implied by (6.6) and the fact that $r \cdot p^{h}\left(q^{h}(c)\right) q^{h}(c) \geq r \cdot p^{l}\left(q^{l}(c)\right) q^{l}(c)$. 


\subsection{Signaling Through the Contract Terms and the Contract Mix}

The above discussion focused on a single franchisor designing a contract for a single franchisee. In reality, franchisors have a number of outlets and while they tend to franchise most of them, they also generally operate some of them directly. I assume that in company-owned outlets, the franchisor keeps control over $q$ (and therefore $p$ ) and a hired manager, who is paid a fixed wage, supervises the outlet. ${ }^{40}$ Note that with a competitive market for such managers, the fixed wage to be paid to each manager will be independent of $T$.

It is necessary to impose a cost related to company-ownership, for example a higher capital cost, to prevent firms from operating all of their units in this context. ${ }^{41}$ This is because the problems related to asymmetric information are assumed not to occur in a vertically integrated firm. ${ }^{42}$ Since signaling involves costly distortions, without some sort of cost attached to company operation, high-value firms in this model would find it in their best interest to operate all of their outlets directly (while low-value franchisors would be indifferent between franchising under $c^{b}$ and operating directly).

Assume the total number of units in the chain, $n$, is fixed, and define $\alpha^{i}$ as the proportion of company-operated stores in a given franchise chain. A separating equilibrium in this case could be characterized by $\hat{\alpha}^{h}>0$ and a contract $\hat{c}=(\hat{r}, \hat{F})$ for franchisors with a high-quality tradename, and $\alpha^{l}=0$ and $c=c^{l}$ for the others. Low-quality franchisors would not want to mimic this offer as long as, for a given $\hat{\alpha}^{h}$,

$$
\hat{\alpha}^{h} \cdot\left(\Pi^{l}-Z^{l}\right)+\left(1-\hat{\alpha}^{h}\right)\left(\hat{r} \cdot \hat{p}^{l} \cdot \hat{q}^{l}+\hat{F}\right) \leq \Pi^{l}
$$

where $\Pi^{l} \geq 0$ as before, and $Z^{i}, i=h, l$ represents the increased capital cost associated with company operation for the high and low-value franchisor respectively. To ensure

40 What is necessary is that the franchisor be able to dictate the quantity to be produced in company-operated outlets, and that the manager's revenues not depend on the "quality" of the franchise. One way to guarantee that managers do not care about the quality of the franchise is to offer them a fixed wage.

41 Gallini and Lutz (1992) do not need to introduce a higher capital cost in their model since they argue that the cost of company-ownership is the inefficiency introduced by a manager who cannot appropriate increases in the resale value of the outlet that are due to his good management. As a result, he picks a lower level of effort than the franchisee does. But since I do not incorporate the franchisee's effort level in the following discussion, it is simpler to think in terms of a capital cost.

42 This assumption is quite customary: see for example Crocker (1983). 
that a separating equilibrium would exist if signaling was achieved strictly through the contract mix, I assume that it is less costly for the high type to increase $\alpha$ than it is for the low type. Combined with the sorting condition imposed above, this also guarantees the existence of a separating equilibrium when a combination of $r$ and $\alpha$ is used to signal the franchisor's type. The contract offered by the high-quality franchisor would again have to satisfy the franchisee's participation constraint, i.e.

$$
(1-\hat{r}) \hat{p}^{h} \cdot \hat{q}^{h}-K \geq \hat{F}
$$

For a given $\alpha^{h}$, the set of separating equilibria implied by these conditions can be reduced to a singleton through the elimination of dominated strategies. This unique separating equilibrium contract $c^{\alpha^{h}}=\left(r^{\alpha^{h}}, F^{\alpha^{h}}\right)$ is the solution to

$$
\max _{r, F}\left\{\alpha^{h}\left(\Pi^{h}-Z\right)+\left(1-\alpha^{h}\right)\left[r \cdot p^{h}\left(q^{h}(c)\right) \cdot q^{h}(c)+F\right]\right\}
$$

subject to

$$
\alpha^{h}\left(\Pi^{l}-Z\right)+\left(1-\alpha^{h}\right)\left[r \cdot p^{l}\left(q^{l}(c)\right) \cdot q^{l}(c)+F\right]=\Pi^{l}
$$

and

$$
(1-r) p^{h}\left(q^{h}(r)\right) q^{h}(r)-K \geq F .
$$

The separating equilibrium might take one of two forms in this case. First, there exists an $\tilde{\alpha}$ such that $c=c^{h}$ when $\alpha^{h} \in[\tilde{\alpha}, 1]$. In other words, all signaling can be achieved through the contract mix rather than the contract terms. In this case, we have that $\alpha^{h}=\tilde{\alpha}$ and $\alpha^{l}=0$, so that $\alpha^{h}>\alpha^{l}$. Extending to a continuum of types again, if signaling is a consideration in the choice of contract mix, and all signaling is achieved through the choice of contract mix, then we should find that $\alpha$ is increasing in $T$.

The second type of equilibrium occurs for values of $\alpha^{h}$ such that $0<\alpha^{h}<\tilde{\alpha}$. In this case, $r>0$ becomes necessary again to achieve separation. In other words, the high-value franchisor uses a combination of $r$ and $\alpha$ to signal his type. With this kind of equilibrium, the signal is the franchisor's stake $(S)$ in the whole chain. If the contract mix and/or royalty rates are used as signaling devices, we should find that this stake increases with $T$. In addition, for a given value of $T, r$ and $\alpha$ should be negatively correlated. 


\section{Appendix B}

Table 3A

OLS Results for Royalty Rates and Franchise Fees

\begin{tabular}{|c|c|c|c|c|}
\hline Variable & Royalty & Fran. Fee & Royalty & Fran. Fee \\
\hline Type1 & $\begin{array}{l}-1.51 \\
(-0.67)\end{array}$ & $\begin{array}{l}-0.90 \\
(-0.16)\end{array}$ & & \\
\hline Type2 & & & $\begin{array}{l}-0.12 \\
(-0.06)\end{array}$ & $\begin{array}{l}-5.58 \\
(-1.13)\end{array}$ \\
\hline Years in bus. & $\begin{array}{c}0.04 \\
(0.53)\end{array}$ & $\begin{array}{l}-0.19 \\
(-1.43)\end{array}$ & $\begin{array}{r}0.12^{*} \\
(2.08)\end{array}$ & $\begin{array}{l}-0.20 \\
(-1.46)\end{array}$ \\
\hline Capital required & $\begin{array}{c}0.84 \\
(-0.90)\end{array}$ & $\begin{array}{l}10.21^{* *} \\
(6.14)\end{array}$ & $\begin{array}{c}-0.50 \\
(-0.86)\end{array}$ & $\begin{array}{l}10.16^{* *} \\
(6.18)\end{array}$ \\
\hline Discontinuations & $\begin{array}{c}0.74 \\
(1.54)\end{array}$ & $\begin{array}{l}-3.62^{* *} \\
(-2.86)\end{array}$ & $\begin{array}{c}0.97^{+} \\
(1.87)\end{array}$ & $\begin{array}{l}-3.41^{* *} \\
(-2.70)\end{array}$ \\
\hline Input Sales & $\begin{array}{c}0.14^{+} \\
(1.76)\end{array}$ & $\begin{array}{l}-0.18 \\
(-0.86)\end{array}$ & $\begin{array}{c}0.17^{+} \\
(1.96)\end{array}$ & $\begin{array}{l}-0.18 \\
(-0.89)\end{array}$ \\
\hline Franch. in 80 & $\begin{array}{l}-0.54 \\
(-0.39)\end{array}$ & $\begin{array}{l}-1.43 \\
(-0.50)\end{array}$ & $\begin{array}{c}0.77 \\
(0.65)\end{array}$ & $\begin{array}{l}-1.49 \\
(-0.53)\end{array}$ \\
\hline Franch. in 81 & $\begin{array}{l}-1.81 \\
(-1.03)\end{array}$ & $\begin{array}{c}6.89 \\
(1.66)\end{array}$ & $\begin{array}{l}-2.10 \\
(-1.22)\end{array}$ & $\begin{array}{c}6.61 \\
(1.61)\end{array}$ \\
\hline Franch. in 82 & $\begin{array}{c}1.89 \\
(1.56)\end{array}$ & $\begin{array}{l}-2.43 \\
(-0.79)\end{array}$ & $\begin{array}{r}2.60^{*} \\
(2.01)\end{array}$ & $\begin{array}{l}-2.13 \\
(-0.70)\end{array}$ \\
\hline Franch. in 83 & $\begin{array}{l}-0.87 \\
(-0.70)\end{array}$ & $\begin{array}{l}-5.00 \\
(-1.65)\end{array}$ & $\begin{array}{c}0.62 \\
(0.52)\end{array}$ & $\begin{array}{l}-4.50 \\
(-1.55)\end{array}$ \\
\hline Franch. in 84 & $\begin{array}{l}-0.59 \\
(-0.43)\end{array}$ & $\begin{array}{c}4.31 \\
(1.14)\end{array}$ & $\begin{array}{c}0.05 \\
(0.03)\end{array}$ & $\begin{array}{c}4.39 \\
(1.20)\end{array}$ \\
\hline Days in training & $\begin{array}{l}-0.01 \\
(-0.16)\end{array}$ & $\begin{array}{c}0.04 \\
(0.44)\end{array}$ & $\begin{array}{c}0.01 \\
(0.40)\end{array}$ & $\begin{array}{c}0.04 \\
(0.49)\end{array}$ \\
\hline Number of States & $\begin{array}{l}-0.01 \\
(-0.24)\end{array}$ & $\begin{array}{l}-0.04 \\
(-0.29)\end{array}$ & $\begin{array}{l}-0.01 \\
(-0.27)\end{array}$ & $\begin{array}{c}0.01 \\
(0.04)\end{array}$ \\
\hline Constant & $\begin{array}{r}6.45^{*} \\
(3.33)\end{array}$ & $\begin{array}{l}19.05^{* *} \\
(3.83)\end{array}$ & $\begin{array}{r}4.25^{*} \\
(2.11)\end{array}$ & $\begin{array}{l}18.34^{* *} \\
(3.70)\end{array}$ \\
\hline Limit Obs. & 2 & 1 & 2 & 1 \\
\hline Non-Limit Obs. & 64 & 65 & 64 & 65 \\
\hline LLF & -157.75 & -218.86 & -160.64 & -218.23 \\
\hline Hetero Coef. $(\beta)$ & $\begin{array}{l}-2.54^{*} \\
(-2.03)\end{array}$ & $\begin{array}{l}-0.78 \\
(-1.04)\end{array}$ & $\begin{array}{c}-0.17 \\
(-0.20)\end{array}$ & $\begin{array}{c}1.10 \\
(1.39)\end{array}$ \\
\hline
\end{tabular}

Asymptotic t-statistics in parentheses.

Two-sided tests: ${ }^{* *}$ significant at the .01 level; $^{*}$ at the .05 level; ${ }^{+}$at the .10 level. 
Table 4A

OLS Results for the Use of Company-Owned Outlets

\begin{tabular}{|c|c|c|c|c|c|c|}
\hline Variable & $\hat{\alpha}$ & $\alpha_{3}$ & $\alpha_{a}$ & $\hat{\alpha}$ & $\alpha_{3}$ & $\alpha_{a}$ \\
\hline Type1 & $\begin{array}{l}-0.93 \\
(-0.93)\end{array}$ & $\begin{array}{l}-12.83 \\
(-0.94)\end{array}$ & $\begin{array}{l}-51.28^{* *} \\
(-3.51)\end{array}$ & & & \\
\hline Type2 & & & & $\begin{array}{c}-0.99 \\
(-1.13)\end{array}$ & $\begin{array}{l}-12.55 \\
(-1.04)\end{array}$ & $\begin{array}{l}-19.81 \\
(-1.05)\end{array}$ \\
\hline Years in bus. & $\begin{array}{l}0.07^{* *} \\
(2.95)\end{array}$ & $\begin{array}{l}1.17^{* *} \\
(3.57)\end{array}$ & $\begin{array}{l}1.16^{* *} \\
(3.27)\end{array}$ & $\begin{array}{l}0.07^{* *} \\
(2.94)\end{array}$ & $\begin{array}{l}1.17^{* *} \\
(3.56)\end{array}$ & $\begin{array}{c}1.50^{* *} \\
(4.11)\end{array}$ \\
\hline Capital required & $\begin{array}{c}0.21 \\
(0.86)\end{array}$ & $\begin{array}{c}3.60 \\
(1.11)\end{array}$ & $\begin{array}{l}-2.22 \\
(-0.55)\end{array}$ & $\begin{array}{c}0.21 \\
(0.89)\end{array}$ & $\begin{array}{c}3.69 \\
(1.14)\end{array}$ & $\begin{array}{l}-5.16 \\
(-1.02)\end{array}$ \\
\hline Discontinuations & $\begin{array}{c}0.15 \\
(0.68)\end{array}$ & $\begin{array}{c}2.86 \\
(0.97)\end{array}$ & $\begin{array}{c}2.51 \\
(0.79)\end{array}$ & $\begin{array}{c}0.17 \\
(0.80)\end{array}$ & $\begin{array}{c}3.18 \\
(1.07)\end{array}$ & $\begin{array}{c}5.63 \\
(1.55)\end{array}$ \\
\hline Input Sales & $\begin{array}{r}0.09^{*} \\
(2.53)\end{array}$ & $\begin{array}{l}1.18^{*} \\
(2.38)\end{array}$ & $\begin{array}{c}0.57 \\
(1.19)\end{array}$ & $\begin{array}{r}0.09^{*} \\
(2.57)\end{array}$ & $\begin{array}{l}1.21^{*} \\
(2.41)\end{array}$ & $\begin{array}{c}0.69 \\
(1.19)\end{array}$ \\
\hline Franch. in 80 & $\begin{array}{l}-0.92^{+} \\
(-1.82)\end{array}$ & $\begin{array}{l}-13.16^{+} \\
(-1.93)\end{array}$ & $\begin{array}{c}6.64 \\
(0.80)\end{array}$ & $\begin{array}{c}-0.96^{+} \\
(-1.91)\end{array}$ & $\begin{array}{l}-13.78^{*} \\
(-2.02)\end{array}$ & $\begin{array}{l}16.92 \\
(1.61)\end{array}$ \\
\hline Franch. in 81 & $\begin{array}{c}-0.41 \\
(-0.57)\end{array}$ & $\begin{array}{c}-7.30 \\
(-0.76)\end{array}$ & $\begin{array}{l}-0.13 \\
(-0.01)\end{array}$ & $\begin{array}{l}-0.49 \\
(-0.69)\end{array}$ & $\begin{array}{l}-8.38 \\
(-0.87)\end{array}$ & $\begin{array}{l}-7.43 \\
(-0.55)\end{array}$ \\
\hline Franch. in 82 & $\begin{array}{l}-0.30 \\
(-0.58)\end{array}$ & $\begin{array}{l}-4.93 \\
(-0.69)\end{array}$ & $\begin{array}{c}4.69 \\
(0.60)\end{array}$ & $\begin{array}{l}-0.32 \\
(-0.60)\end{array}$ & $\begin{array}{l}-5.17 \\
(-0.73)\end{array}$ & $\begin{array}{l}23.52^{* *} \\
(2.98)\end{array}$ \\
\hline Franch. in 83 & $\begin{array}{c}0.25 \\
(0.48)\end{array}$ & $\begin{array}{c}4.10 \\
(0.59)\end{array}$ & $\begin{array}{l}23.65^{* *} \\
(3.65)\end{array}$ & $\begin{array}{c}0.21 \\
(0.42)\end{array}$ & $\begin{array}{c}3.43 \\
(0.51)\end{array}$ & $\begin{array}{l}23.72^{* *} \\
(3.30)\end{array}$ \\
\hline Franch. in 84 & $\begin{array}{l}-0.45 \\
(-0.70)\end{array}$ & $\begin{array}{c}-5.55 \\
(-0.63)\end{array}$ & $\begin{array}{l}25.86^{* *} \\
(2.99)\end{array}$ & $\begin{array}{l}-0.53 \\
(-0.84)\end{array}$ & $\begin{array}{l}-6.70 \\
(-0.78)\end{array}$ & $\begin{array}{l}46.20^{* *} \\
(5.60)\end{array}$ \\
\hline Days in training & $\begin{array}{l}-0.00 \\
(-0.34)\end{array}$ & $\begin{array}{l}-0.08 \\
(-0.42)\end{array}$ & $\begin{array}{c}0.39^{+} \\
(1.77)\end{array}$ & $\begin{array}{l}-0.00 \\
(-0.18)\end{array}$ & $\begin{array}{l}-0.05 \\
(-0.26)\end{array}$ & $\begin{array}{l}0.81^{* *} \\
(3.24)\end{array}$ \\
\hline Number of States & $\begin{array}{l}-0.00 \\
(-0.06)\end{array}$ & $\begin{array}{c}0.09 \\
(0.30)\end{array}$ & $\begin{array}{l}-0.86^{+} \\
(-1.86)\end{array}$ & $\begin{array}{c}0.01 \\
(0.40)\end{array}$ & $\begin{array}{c}0.23 \\
(0.73)\end{array}$ & $\begin{array}{l}-0.26 \\
(-0.51)\end{array}$ \\
\hline Constant & $\begin{array}{l}-0.01 \\
(-0.02)\end{array}$ & $\begin{array}{l}-2.50 \\
(-0.22)\end{array}$ & $\begin{array}{l}-3.88 \\
(-0.32)\end{array}$ & $\begin{array}{l}-0.10 \\
(-0.12)\end{array}$ & $\begin{array}{l}-3.40 \\
(-0.30)\end{array}$ & $\begin{array}{l}-22.38^{+} \\
(-1.66)\end{array}$ \\
\hline Lower Limit Obs. & 11 & 11 & 12 & 11 & 11 & 12 \\
\hline Upper Limit Obs. & 0 & 0 & 1 & 20 & 20 & 1 \\
\hline Non-Limit Obs. & 55 & 55 & 53 & 55 & 55 & 53 \\
\hline $\begin{array}{l}\text { LLF } \\
\text { Hetero Coef. }(\beta)\end{array}$ & $\begin{array}{c}-97.77 \\
-0.55 \\
(-0.82)\end{array}$ & $\begin{array}{r}-238.27 \\
-0.90 \\
(-1.31)\end{array}$ & $\begin{array}{c}-236.78 \\
-3.24^{* *} \\
(-3.62)\end{array}$ & $\begin{array}{c}-97.56 \\
-0.87 \\
(-1.19)\end{array}$ & $\begin{array}{r}-238.17 \\
-0.86 \\
(-1.13)\end{array}$ & $\begin{array}{c}-249.37 \\
-5.71^{* *} \\
(-2.79)\end{array}$ \\
\hline
\end{tabular}

Asymptotic t-statistics in parentheses.

Two-sided tests: ${ }^{* *}$ significant at the .01 level; $^{*}$ at the .05 level; ${ }^{+}$at the .10 level. 
Table 5A

OLS Results for the Stake of the Franchisor in Downstream Operations

\begin{tabular}{|c|c|c|c|c|}
\hline Variable & $S_{3}$ & $S_{a}$ & $S_{3}$ & $S_{a}$ \\
\hline Type1 & $\begin{array}{l}-12.53 \\
(-0.83)\end{array}$ & $\begin{array}{l}-61.79^{* *} \\
(-3.70)\end{array}$ & & \\
\hline Type2 & & & $\begin{array}{l}-10.42 \\
(-0.80)\end{array}$ & $\begin{array}{l}-11.39 \\
(-0.81)\end{array}$ \\
\hline Years in bus. & $\begin{array}{l}0.95^{* *} \\
(2.63)\end{array}$ & $\begin{array}{l}0.99^{* *} \\
(2.59)\end{array}$ & $\begin{array}{r}0.94^{*} \\
(2.61)\end{array}$ & $\begin{array}{l}1.40^{* *} \\
(3.38)\end{array}$ \\
\hline Capital required & $\begin{array}{c}3.16 \\
(0.86)\end{array}$ & $\begin{array}{l}-1.72 \\
(-0.39)\end{array}$ & $\begin{array}{c}3.32 \\
(0.90)\end{array}$ & $\begin{array}{l}-5.33 \\
(-0.92)\end{array}$ \\
\hline Discontinuations & $\begin{array}{c}4.97 \\
(1.54)\end{array}$ & $\begin{array}{r}6.73^{*} \\
(1.99)\end{array}$ & $\begin{array}{c}5.32 \\
(1.63)\end{array}$ & $\begin{array}{r}6.44^{+} \\
(1.70)\end{array}$ \\
\hline Input Sales & $\begin{array}{c}0.74 \\
(1.37)\end{array}$ & $\begin{array}{c}0.32 \\
(0.67)\end{array}$ & $\begin{array}{c}0.76 \\
(1.40)\end{array}$ & $\begin{array}{c}0.46 \\
(1.09)\end{array}$ \\
\hline Franch. in 80 & $\begin{array}{l}-14.89^{+} \\
(-1.95)\end{array}$ & $\begin{array}{l}13.35 \\
(1.57)\end{array}$ & $\begin{array}{l}-15.37^{*} \\
(-2.02)\end{array}$ & $\begin{array}{l}20.36^{*} \\
(2.38)\end{array}$ \\
\hline Franch. in 81 & $\begin{array}{l}-19.52^{+} \\
(-1.79)\end{array}$ & $\begin{array}{l}-27.26^{*} \\
(-2.03)\end{array}$ & $\begin{array}{l}-20.41^{+} \\
(-1.87)\end{array}$ & $\begin{array}{l}-28.29^{*} \\
(-2.18)\end{array}$ \\
\hline Franch. in 82 & $\begin{array}{l}-8.82 \\
(-1.09)\end{array}$ & $\begin{array}{l}10.90 \\
(1.33)\end{array}$ & $\begin{array}{l}-9.17 \\
(-1.13)\end{array}$ & $\begin{array}{l}31.14^{* *} \\
(3.26)\end{array}$ \\
\hline Franch. in 83 & $\begin{array}{c}0.82 \\
(0.10)\end{array}$ & $\begin{array}{l}28.42^{* *} \\
(4.29)\end{array}$ & $\begin{array}{l}-0.06 \\
(-0.01)\end{array}$ & $\begin{array}{l}31.26^{* *} \\
(4.72)\end{array}$ \\
\hline Franch. in 84 & $\begin{array}{l}-13.82 \\
(-1.40)\end{array}$ & $\begin{array}{l}26.21^{* *} \\
(2.78)\end{array}$ & $\begin{array}{l}-15.03 \\
(-1.54)\end{array}$ & $\begin{array}{l}45.09^{* *} \\
(4.62)\end{array}$ \\
\hline Days in training & $\begin{array}{c}0.03 \\
(0.15)\end{array}$ & $\begin{array}{r}0.57^{*} \\
(2.53)\end{array}$ & $\begin{array}{c}0.06 \\
(0.30)\end{array}$ & $\begin{array}{l}1.14^{* *} \\
(4.59)\end{array}$ \\
\hline Number of States & $\begin{array}{c}0.26 \\
(0.77)\end{array}$ & $\begin{array}{l}-0.65 \\
(-1.48)\end{array}$ & $\begin{array}{c}0.37 \\
(1.08)\end{array}$ & $\begin{array}{l}-0.13 \\
(-0.59)\end{array}$ \\
\hline Constant & $\begin{array}{l}10.87 \\
(0.88)\end{array}$ & $\begin{array}{c}4.42^{+} \\
(0.37)\end{array}$ & $\begin{array}{c}9.86 \\
(0.79)\end{array}$ & $\begin{array}{l}-12.38 \\
(-0.94)\end{array}$ \\
\hline Lower Limit Obs. & 1 & 1 & 1 & 1 \\
\hline Upper Limit Obs. & 0 & 1 & 0 & 1 \\
\hline Non-Limit Obs. & 65 & 64 & 65 & 64 \\
\hline $\begin{array}{l}\text { LLF } \\
\text { Hetero Coef. }(\beta)\end{array}$ & $\begin{array}{r}-281.71 \\
-0.88 \\
(-1.38)\end{array}$ & $\begin{array}{c}-282.67 \\
-4.12^{* *} \\
(-3.67)\end{array}$ & $\begin{array}{c}-281.73 \\
-0.76 \\
(-1.17)\end{array}$ & $\begin{array}{c}-293.22 \\
-5.39^{* *} \\
(-2.67)\end{array}$ \\
\hline
\end{tabular}

Asymptotic t-statistics in parentheses.

Two-sided tests: ${ }^{* *}$ significant at the .01 level; ${ }^{*}$ at the .05 level; ${ }^{+}$at the .10 level. 